


\section{A Orientación editorial}

\section{Enfoque y alcance}

La Revista de Arquitectura (ISSN 1657-0308 Impresa y E-ISSN 2357-626X en línea) es una publicación seriada de acceso abierto, arbitrada mediante revisión por pares (doble ciego) e indexada, en donde se publican resultados de investigación originales e inéditos.

Está dirigida a la comunidad académica y profesional de las áreas afines a la disciplina. Es editada por la Facultad de Diseño y el Centro de Investigaciones (CIFAR) de la Universidad Católica de Colombia en Bogotá (Colombia).

La principal área científica a la que se adscribe la Revista de Arquitectura según la OCDE es:

Gran área: 6. Humanidades

Área: 6.D. Arte

Disciplina: 6D07. Arquitectura y Urbanismo

También se publican artículos de las disciplinas como 2A02, Ingeniería arquitectónica; 5G03, Estudios urbanos (planificación y desarrollo); 6D07, Diseño.

Los objetivos de la Revista de Arquitectura son:

- Promover la divulgación y difusión del conocimiento generado a nivel local, nacional e internacional

- Conformar un espacio para la construcción de comunidades académicas y la discusión en torno a las secciones definidas.

- Fomentar la diversidad institucional y geográfica de los autores que participan en la publicación.

- Potenciar la discusión de experiencias e intercambios científicos entre investigadores y profesionales.

- Contribuir a la visión integral de la arquitectura, por medio de la concurrencia y articulación de las secciones mediante la publicación de artículos de calidad.

- Publicar artículos originales e inéditos que han pasado por revisión de pares, para asegurar que se cumplen las normas éticas, de calidad, validez científica, editorial e investigativa.

- Fomentar la divulgación de las investigaciones y actividades desarrolladas en la Universidad Católica de Colombia.
Palabras clave de la Revista de Arquitectura: arquitectura, diseño, educación arquitectónica, proyecto y construcción, urbanismo.

Idiomas de publicación: español, inglés, portugués y francés. Título abreviado: Rev. Arquit.

\section{Titulo corto: RevArq}

\section{Políticas de sección}

La revista se estructura en tres secciones correspondientes a las líneas de investigación activas y aprobadas por la institución, y dos complementarias, que presentan dinámicas propias de la Facultad de Diseño y las publicaciones relacionadas con la disciplina.

Cultura y espacio urbano. En esta sección se publican los artículos que se refieren a fenómenos sociales en relación con el espacio urbano, atendiendo aspectos de la historia, el patrimonio cultural y físico, y la estructura formal de las ciudades y el territorio.

Proyecto arquitectónico y urbano. En esta sección se presentan artículos sobre el concepto de proyecto, entendido como elemento que define y orienta las condiciones proyectuales que devienen en los hechos arquitectónicos o urbanos, y la forma como estos se convierten en un proceso de investigación y nuevo de conocimiento. También se presentan proyectos que sean resultados de investigación, los cuales se validan por medio de la ejecución y transformación en obra construida del proceso investigativo. También se contempla la publicación de investigaciones relacionadas con la pedagogía y didáctica de la arquitectura, el urbanismo y el diseño.

Tecnología, medioambiente y sostenibilidad. En esta sección se presentan artículos acerca de sistemas estructurales, materiales y procesos constructivos, medioambiente y gestión, relacionados con los entornos social-cultural, ecológico y económico.

Desde la Facultad. En esta sección se publican artículos generados en la Facultad de Diseño, relacionados con las actividades de docencia, extensión, formación en investigación o internacionalización, las cuales son reflejo de la dinámica y de las actividades realizadas por docentes, estudiantes y egresados; esta sección no puede superar el $20 \%$ del contenido.

Textos. En esta sección se publican reseñas, traducciones y memorias de eventos relacionados con las publicaciones en Arquitectura y Urbanismo.

\section{A Frecuencia de publicación}

Desde 1999 y hasta el 2015, la Revista de Arquitectura publicó un volumen al año, a partir del 2016 se publicarán dos números por año en periodo anticipado, enero-junio y julio-diciembre, pero también maneja la publicación anticipada en línea de los artículos aceptados (versión Post-print del autor).

La Revista de Arquitectura se divulga mediante versiones digitales (PDF, HTML, XML) e impresas con un tiraje de 700 ejemplares, los tiempos de producción de estas versiones dependerán de los cronogramas establecidos por la editorial.

Los tiempos de recepción-revisión-aceptación pueden tardar entre seis y doce meses dependiendo del flujo editorial de cada sección y del proceso de revisión y edición adelantado.

Con el usuario y contraseña asignados, los autores pueden ingresar a la plataforma de gestión editorial y verificar el estado de revisión, edición o publicación del artículo.
A Canje

La Revista de Arquitectura está interesada en establecer canje con publicaciones académicas, profesionales o científicas del área de Arquitectura y Urbanismo, como medio de reconocimiento y discusión de la producción científica en el campo de acción de la publicación.

\section{Mecanismo}

Para establecer canje por favor descargar diligenciar y enviar el formato: RevArq FP20 Canjes

Universidad Católica de Colombia (2016, julio-diciembre). Revista de Arquitectura, 18(2), 1-136. Doi: 10.14718

ISSN: 1657-0308 E-ISSN: 2357-626X

Especificaciones:

Formato: $34 \times 24 \mathrm{~cm}$

Papel: Mate $115 \mathrm{~g}$

Tintas: Negro y policromía

\section{(A) Contacto}

Dirección postal:

Avenida Caracas No. 46-72. Universidad Católica de Colombia. Bogotá D.C.(Colombia)

Código postal: 111311

Facultad de Diseño, Centro de Investigaciones (CIFAR). Sede El Claustro. Bloque "L", 4 piso, Diag. 46a No. 15b-10. Editor, Arq. César Andrés Eligio Triana

Teléfonos: +57 (1) 3277300 - 3277333

Ext. 3109; 3112 o 5146

Fax: +57 (1) 2858895

Correo electrónico:

revistadearquitectura@ucatolica.edu.co cifar@ucatolica.edu.co

\section{Página WEB}

www.ucatolica.edu.co vínculo Revistas científicas http://publicaciones.ucatolica.edu.co/revistas-cientificas http://editorial.ucatolica.edu.co/ojsucatolica/revistas ucatoli$\mathrm{ca} /$ index.php/RevArq 


\section{CONTENDO}

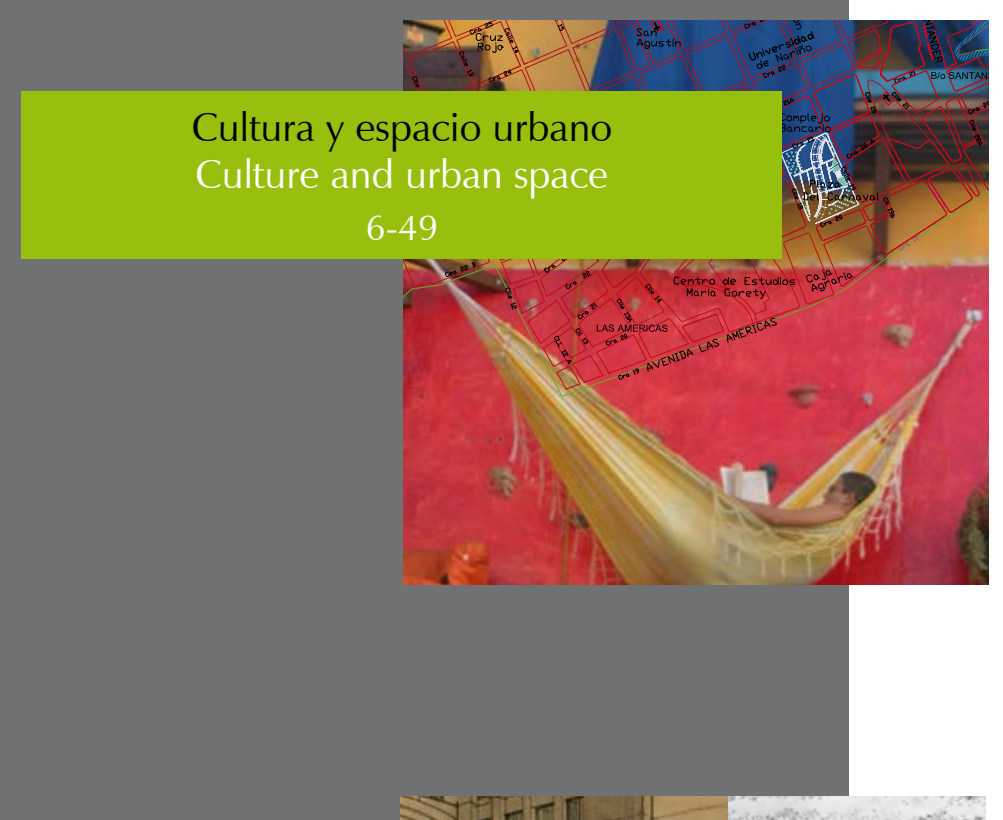

Estructura de indicadores de habitabilidad del espacio público en ciudades latinoamericanas

Pablo Páramo, Andrea Burbano, Diana Fernández-Londoño Pág. 6

Além do público/privado

Intervenções temporárias e criação de

espaços coletivos no Rio de Janeiro

Adriana Sansão-Fontes, Aline Couri-Fabião

Pág. 27

Conservar o renovar: dinámicas de construcción en el centro histórico de tres ciudades intermedias patrimoniales

Una mirada a través de las licencias urbanísticas

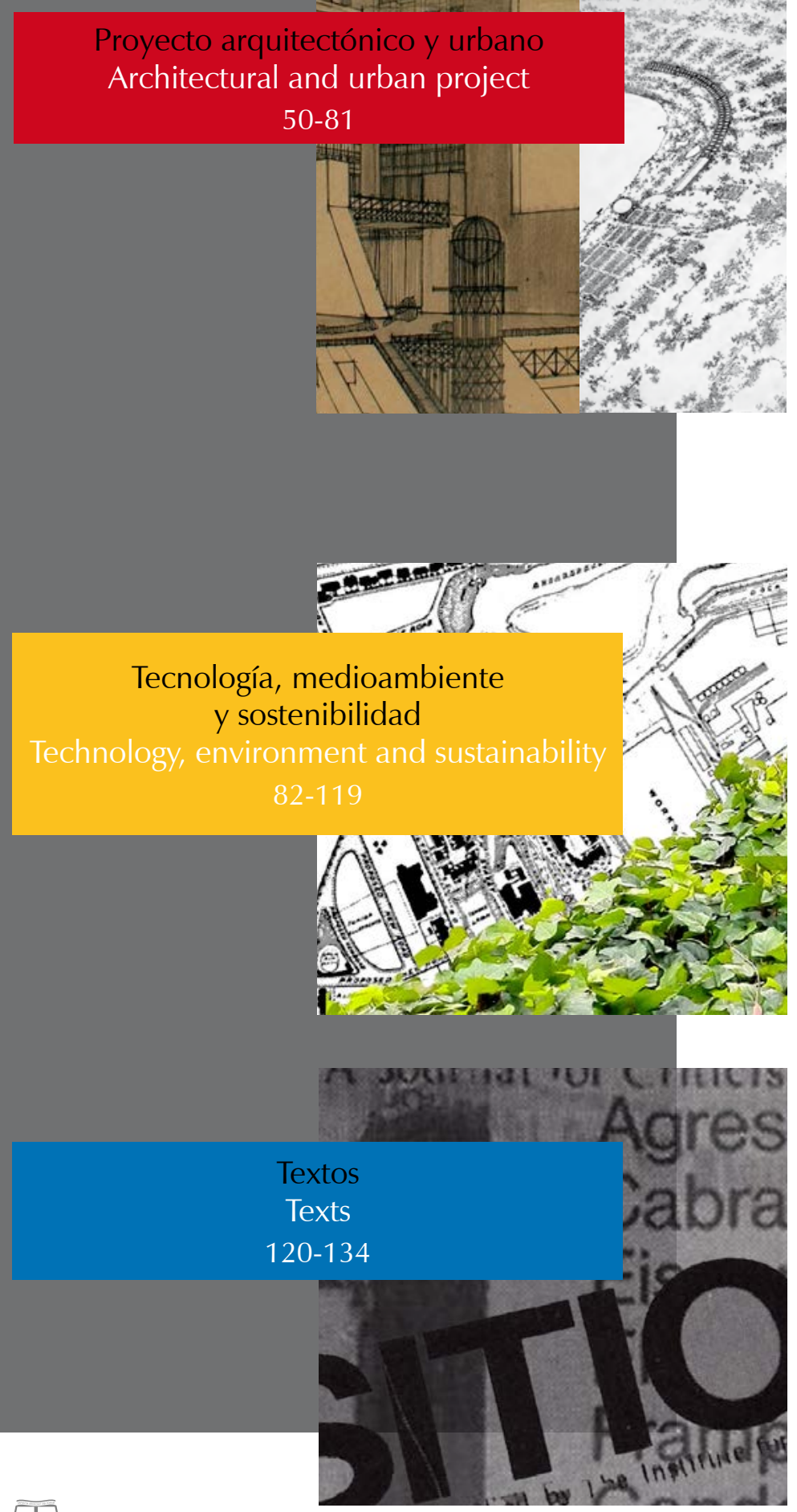

El paisaje del hábitat horizontal:

la Unidad del Tuscolano en Roma y el Poblado de Entrevías en Madrid

Federico Colella

Evolución paralela del relato fílmico y la arquitectura de los cines entre 1900 y 1930

Atención especial al caso español

Ana C. Lavilla-Iribarren

El plan, acto mesiánico del proyectista

La situación histórica del diseño en

la utopía modernizante

Valentina Mejía-Amézquita, Adolfo León Grisales-Vargas Pág. 71

Resiliencia a inundaciones:

nuevo paradigma para el diseño urbano

Luis Fernando Molina-Prieto

Pág. 82

Acceso solar en la arquitectura y la ciudad

Aproximación histórica

Ricardo Franco-Medina, Pedro Juan Bright-Samper

Pág. 95

\section{Campus universitario sustentable}

Lina Johanna Zapata-González, Andrés Quiceno-Hoyos, Luisa Fernanda Tabares-Hidalgo

La crítica arquitectónica como objeto de investigación [La critique architecturale, objet de recherche]

Hélène Jannière

Traductores: Andrés Ávila-Gómez, Diana Carolina Ruiz Pág. 120 


\title{
Estructura de indicadores de habitabilidad del espacio público en ciudades latinoamericanas
}

\author{
Pablo Páramo, Andrea Burbano \\ Universidad Pedagógica Nacional, Bogotá (Colombia) \\ Diana Fernández-Londoño \\ Universidad Piloto de Colombia, Bogotá (Colombia)
}

Páramo, P., Burbano, A. \& Fernández- : Psicólogo, Universidad Católica de Colombia, Bogotá (Colombia). Londoño, D. (2016). Estructura $\quad$ Master of Science, University of Surrey. Reino Unido.

de indicadores de habitabi-

lidad del espacio público en

ciudades latinoamericanas.

Revista de Arquitectura,

18(2), 6-26. doi:10.14718/

RevArq.2016.18.2.2

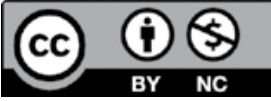

PhD en Psicología, Centro de Graduados de la Universidad de la

Ciudad de Nueva York (EE.UU.)

Profesor Titular, programa de Doctorado Interinstitucional en Edu-

cación, Universidad Pedagógica Nacional.

http://orcid.org/0000-0002-455I-3040

pdeparamo@gmail.com

Andrea Burbano

Arquitecta, Universidad de La Salle, Bogotá (Colombia).

Magíster en Gestión Urbana, Universidad Piloto de Colombia, Bo-

gotá (Colombia).

PhD en Estudios Territoriales, Universidad de Caldas, Manizales (Colombia).

Profesora e investigadora del Departamento de Posgrado, Universi dad Pedagógica Nacional, Bogotá (Colombia).

http://orcid.org/0000-0003-2037-5603

arqburbano@gmail.com

Diana Fernández-Londoño

Arquitecta, Fundación Universitaria Popayán (Colombia).

Especialista en Planificación y Administración del Desarrollo Regional, Universidad de los Andes, Bogotá (Colombia).

Magíster en Gestión Urbana, Universidad Piloto de Colombia, Bogotá (Colombia).

Profesora del Programa de Arquitectura, Universidad Piloto de

Colombia, Bogotá (Colombia).

http://orcid.org/0000-000 I-5348-4529

marcela.fernandez@outlook.com

\section{Resumen}

A partir de una revisión documental, este trabajo recoge los indicadores existentes para evaluar la calidad de los espacios públicos de varias ciudades del mundo incluyendo aquellas latinoamericanas que han sido reconocidas por sus logros en estos espacios. Se propone una estructura organizativa para dichos indicadores a partir de la función que cumple el espacio público con el propósito de facilitar su gestión desde las distintas entidades que tienen injerencia sobre este y proyectarlo como un espacio habitable. La estructura plantea la organización de los indicadores a partir de las funciones y las condiciones físicas que debe cumplir el espacio público para que este sea habitable. El trabajo hace una exploración documental sobre los indicadores que miden la calidad de vida en las ciudades, en particular de sus espacios públicos, a partir de propuestas académicas y técnicas que se manejan en distintos organismos internacionales e instituciones de gobierno que administran las ciudades. Se analiza la importancia que le dan los distintos entes administrativos a estos indicadores, y finalmente se propone una estructura que busca organizar dichos indicadores existentes, incluyendo algunos nuevos, para facilitar su gestión.

Palabras clave: calidad de vida urbana, indicadores urbanos, espacio abierto, gestión urbana.

\section{Structure of indicators of public space habitability in Latin American cities}

Abstract

Based on a documentary review, this paper presents the existing indicators that evaluate the quality of public space in several cities around the world, including those cities in Latin America that have been recognized for their achievements regarding these spaces. An organizational structure of the indicators is proposed based on the role of public space in order to facilitate its management by different competent entities and to design it as a habitable space. The suggested structure for the organization of indicators is based on the functions and physical conditions that public space must have in order to be habitable. The paper offers a documentary exploration of indicators that measure the quality of life in cities, particularly in their public spaces, based on academic and technical proposals used by different international organizations and government institutions that manage these cities. It also analyzes the importance given to these indicators by different administrative entities, and finally proposes a structure that seeks to organize the existing indicators, while including some new ones, to facilitate the management of public spaces.

Keywords: Quality of urban life, urban indicators, open space, urban management.

Recibido: noviembre 08/2015_Evaluado: octubre 18/2016_Aceptado: noviembre 01/2016 


\section{Introducción}

El presente artículo se enmarca dentro del proyecto: "Estudio comparado de espacio público en Latinoamérica", financiado por la maestría en Gestión Urbana de la Universidad Piloto de Colombia para el año 2015, cuyo propósito se orientó a realizar una investigación comparada sobre la habitabilidad del espacio público en ciudades latinoamericanas que han recibido reconocimiento internacional por sus logros con proyectos de intervención espacial. El artículo parte de destacar la importancia que ha venido cobrando el espacio público en varias ciudades latinoamericanas, dentro de lo cual se identifican algunos antecedentes importantes de los estudios sobre la habitabilidad de dicho espacio y del surgimiento de indicadores para evaluarla. Posteriormente, justifica la necesidad de sumar a los indicadores ya existentes algunos nuevos y organizarlos en una estructura que contenga una batería que permita hacerle monitoreo al desarrollo de los espacios públicos, servir de línea base para evaluar la efectividad de políticas públicas y proyectar su habitabilidad con miras a recuperar su valor a fin de mejorar la calidad de vida en las ciudades latinoamericanas.

\section{Importancia del espacio público en ciudades latinoamericanas}

El espacio público de las ciudades latinoamericanas está siendo actualmente objeto de gestión con el fin de contribuir al mejoramiento de la calidad de vida de sus habitantes, a partir de la creación de nuevos lugares públicos y la recuperación de espacios abandonados, dada la importancia que se le viene dando para el sostenimiento de las distintas prácticas sociales que se sitúan en el espacio público, entre las que se pueden mencionar: el comercio, la protesta ciudadana, el arte, la lúdica y el entretenimiento, el deporte, la religiosidad y las expresiones de los distintos movimientos sociales. Desde esta perspectiva, se destaca la importancia del espacio público como una construcción social que produce y reproduce una serie de prácticas sociales a partir de la gestión que se hace de este desde la normatividad y de los discursos que se elaboran para reproducir estas prácticas, a partir de la función que supuestamente debe cumplir (Carr, Francis, Riviin y Stone, 1992; Gehl, 1997; Morril, Snow y White 2005; Franck y Stevens, 2007; Gehl y Svarre, 2013; Torres, 2014) con repercusiones en la vida social de los habitantes de las ciudades.

Prueba del relieve que ha tenido el espacio público es que, gracias a este, varias ciudades en Latinoamérica han sido merecedoras de reconocimientos internacionales por sus aportes a las estrategias de reactivación de los espacios públicos y el mejoramiento en sus dinámicas administrativas con propuestas innovadoras y reestructuradas a las exigencias actuales. Así ocurre, por ejemplo, con ciudades de Brasil, México, Ecuador, Uruguay, Perú, Argentina y Colombia. En estos países se ubican ciudades premiadas o reconocidas como "mejores ciudades" (Loja y Lima); "ciudades verdes de América Latina" (São Paulo, Buenos Aires, Quito, Curitiba, Puebla, Bello Horizonte, Porto Alegre y Ciudad de México); "ciudades educadoras" (Rosario, en Argentina, Santa Cruz de la Sierra en Bolivia, Belo Horizonte en Brasil, Medellín en Colombia, Quito en Ecuador, Ciudad de México en México); "ciudades innovadoras" (Medellín y Santiago de Chile); "ciudades inteligentes en América Latina" (Medellín, Rio de Janeiro y Curitiba); "ciudades más amigables del mundo" (Buenos Aires, Río de Janeiro, São Paulo y Bogotá); y por "el premio mundial de la ciudad", Lee Kuan Yew World City Prize (Medellín).

Así mismo, se ha visto que el interés por definir políticas y promover investigaciones sobre espacio público en los últimos años se refleja en la organización de seminarios internacionales, entre los que se destacan: el Foro Mundial Urbano, promovido por la ONU; los que se vienen organizando en Bogotá, por el Departamento Administrativo de la Defensoría del Espacio Público (DADEP) junto con los foros sobre parques, organizados por el Instituto Distrital de Recreación y Deporte de Bogotá (IDRD); en Buenos Aires, el denominado "La calle"; los seminarios sobre el Derecho a la Ciudad, coordinados por Clacso; y las intervenciones que se hacen desde distintas ONG, como: Public Space Projet (PSP), la Fundación Despacio, el Observatorio de Derecho a la Ciudad, de Buenos Aires, y la Fundación Espacio Público: comunicarte es tu derecho, de Caracas, entre otras.

La gran mayoría de propuestas actuales para invertir y transformar el espacio público han surgido como iniciativa de las administraciones de turno en las ciudades, que si bien no obedecen necesariamente a políticas claras derivadas de sus Cartas Magnas o leyes específicas, sí responden a programas de gobierno que buscan mejorar las características de la ciudad ya sea como inversión para atraer el turismo, las inversiones en bienes raíces o negocios propios de la expansión inmobiliaria y de servicios y, por consiguiente, mejorar la economía o atender compromisos con políticas más amplias de orden internacional como las que generan compromiso con el medio ambiente o en búsqueda de atender necesidades puntuales como la movilidad y el transporte público. 
Son las alcaldías de las ciudades las que mediante instrumentos de regulación, principalmente de planes maestros y de manejo, acuerdos de los consejos municipales, planes de ordenamiento del territorio, de desarrollo, de acción y otras normas que hacen referencia a programas específicos, las que promueven proyectos tales como: el uso de las ciclorrutas o de sistemas de transporte masivo mediante reglamentos del usuario, entre otros Plan Maestro de Ciclorrutas de la ciudad de Bogotá (1998), Plan Maestro de Movilidad para Bogotá (Decreto 319 de 2006), Plan Maestro de Espacio Público de Bogotá (Decreto 215 de 2005)—.

Con el propósito de evaluar la eficacia de las políticas de espacio público en el contexto latinoamericano, se han creado algunos indicadores, principalmente de orden cuantitativo, aunque se echa de menos, como lo ha señalado Páramo (2010), un mayor desarrollo de indicadores que permitan evaluar el espacio público desde una visión ampliada, que incluya indicadores de orden subjetivo o de percepción que identifiquen los intereses de la población que lo habita. Es por esto que esta investigación se orientó a identificar y sistematizar los indicadores de los que hacen uso las instituciones de gobierno, además de los sugeridos por organismos internacionales y la academia, y proponer algunos otros que, en su conjunto, permitirían hacer una gestión más eficiente y eficaz en el seguimiento de las políticas y los programas que buscan crear y mejorar el espacio público. Por lo anterior, la presente investigación partió de las siguientes preguntas: ¿cuáles son los indicadores que existen actualmente para evaluar el espacio público desde los organismos internacionales, las instituciones de gobierno y los académicos?, ¿cuál es el peso relativo que se les da en las distintas entidades de gobierno? y ¿̇cuál puede ser una estructura que permita agruparlos para contribuir a una gestión más eficiente del espacio público?

Con miras a identificar indicadores del desarrollo del espacio público se partió de la exploración de las mediciones existentes en ciudades destacadas por su interés en desarrollar este espacio, entre las cuales se encuentran São Paulo, Rio de Janeiro, Belo Horizonte, Porto Alegre, Ciudad de México, Puebla, Guadalajara, Quito, Loja, Montevideo, Lima, Bogotá, Medellín y Buenos Aires.

La importancia de reconocer lo que se viene haciendo en estas ciudades radica en que se pueden identificar los aspectos normativos, incluidos los indicadores que se han creado y que han contribuido a la buena gestión del espacio público, con el fin de direccionar las políticas y los programas de espacio público en otras ciudades de la región, incluidas las colombianas, tomando en cuenta principalmente los intereses de los habitantes, lo cual aseguraría unas inversiones de recursos acordes con las necesidades y los deseos ciudadanos.

\section{Antecedentes en el estudio de la habitabilidad e indicadores urbanos}

La revisión de la literatura sobre el tema permite observar que, por lo general, la discusión sobre la habitabilidad de los espacios públicos se ha desarrollado de manera gradual e indirecta en las ciudades latinoamericanas, cuando debido a los cambios acelerados de los espacios urbanos fue haciéndose cada vez más evidente la necesidad de buscar el restablecimiento del uso y la apropiación del espacio público de las ciudades como componente importante de las mismas, y como referente de calidad de vida urbana. Desde entonces se han realizado estudios como el de la Organización de las Naciones Unidas (ONU) en 1992, que consideró tres dimensiones generales de las cuales se podrían derivar variables y sus respectivos indicadores: factores ambientales, económicos y sociales. A partir de entonces, la ONU realizó la primera recopilación mundial de indicadores urbanos, listado usado como punto de referencia inicial. Aunque es un referente bastante amplio por el extenso contenido que relaciona todos los temas concernientes a la ciudad, es tenido en cuenta por su estructura general como el gran referente para propuestas posteriores.

Desde las instituciones y la academia se han propuesto también distintas baterías de indicadores con el propósito de evaluar la calidad de vida, que a su vez incluyen al espacio público como categorías de análisis. Se destacan en este interés los trabajos de: Leva (2005); Páramo y Burbano (2013, 2014b y 2014b); el documento Benchmark, denominado "Bogotá 21", hacia una metrópoli de clase mundial orientada al transporte público (Wessels, Pardo y Bocarejo, 2012); los indicadores de calidad de vida urbana y espacio público tenidos en cuenta por la Secretaría Distrital de Planeación de Bogotá D.C.; la Defensoría del Espacio Público; la Encuesta Nacional de Calidad de Vida 2014 del DANE; y los indicadores de calidad de vida manejados por el programa Red Colombiana de Ciudades Cómo Vamos (2014). Del mismo modo, es importante mencionar el conjunto de indicadores compilado por el Banco Mundial, al igual que la recopilación de datos de List of Habitat Agenda Indicators, WHO List of City Indicators, Unesco List of Indicators of racism and ethnic discrimination, European Foundation suggested indicators, Set of urban indicators used by FCM. Lo anterior, con el fin de reconocer y clasificar en categorías los indicadores de calidad de vida de estos listados que están relacionados 
con el espacio público y que deberán ser incluidos en una propuesta integral dirigida a la valoración de habitabilidad de los mismos.

Es importante hacer notar que la investigación de indicadores sociales comenzó en los años veinte y treinta del siglo pasado. Se inició debido a la necesidad de intervenir las ciudades tras la fuerte transformación por cuenta de la industrialización, lo que dio lugar a la expresión "calidad de vida", que comienza a aparecer en los debates públicos en torno al medio ambiente (Leva, 2005). En ese momento se esgrimen las primeras relaciones de hábitat y calidad de vida a nivel de ciudad como sistema, y su funcionamiento en general, direccionando las definiciones al ámbito privado y los servicios. Es de anotar que para ese momento la discusión del espacio público en relación con la calidad de vida empezaba a evolucionar desde su articulación con la dimensión urbana, como parte de uno de los componentes por tener en cuenta para determinar la calidad de vida urbana como componente esencial del sistema de ciudad.

A pesar de la clara relación entre hábitat y calidad de vida de las personas, Páramo y Burbano (2013) hacen notar que los espacios públicos han evolucionado de una manera desagregada en las ciudades. Contrario al crecimiento y abastecimiento de servicios de las mismas, las nuevas construcciones tomaron la prioridad del espacio urbano y le dieron la espalda al espacio público. Las múltiples actividades que se acostumbraban realizar en dichos espacios empezaron a desplazarse a espacios privados y a modificar conductas en los individuos haciendo que estos cada vez frecuentaran menos los parques, las plazas, las calles. Estos cambios generaron transformaciones en los conceptos acerca del espacio público y en las dinámicas del uso, y de esta manera muchos de estos espacios fueron reemplazados por espacios privados que buscaban complementar las actividades que el público ya no parecía ofrecer como la seguridad, la comodidad y el aseo (Páramo, 2010).

La presión creciente de las ciudades para atraer recursos humanos y económicos impulsó los estudios sobre el tema de calidad de vida relacionada con el espacio público. Se ha podido establecer que para atraer flujos significativos de personas se debe disponer de espacios públicos cuidadosamente diseñados que son la infraestructura sobre la cual se sostiene el proceso que refuerza la vida urbana. De aquí se desprende el hecho de que la vida es un proceso que se retroalimenta (Gehl, 2014). Dicha retroalimentación es identificada como necesaria, entre la relación directa que sostienen los conceptos de calidad de vida, espacio público y hábitat urba- no. La relación se plantea teniendo en cuenta que un espacio se considera habitable en tanto satisface necesidades humanas. En el caso particular del espacio público, debe cumplir con ciertas condiciones recomendables, tanto físicas como no físicas, que estén en relación (Saldarriaga, 1981). La definición de hábitat conlleva la relación entre desarrollo armónico y calidad de vida de las personas, la productividad de la ciudad, la inclusión social y el reconocimiento de las identidades individual y colectiva (Alfonso, 2010; Definición de Hábitat, 2008).

\section{Metodología}

A partir de dichos estudios, y entendiendo la necesidad de aportar a la implementación de la estimación sobre habitabilidad del espacio público que contribuya al mejoramiento de la calidad de vida de sus habitantes, se plantea el presente artículo, cuyo fin es proponer a la gestión de las ciudades latinoamericanas una estructura que integre indicadores cuantitativos y cualitativos que contribuyan a la valoración de la habitabilidad de sus espacios públicos y, por consiguiente, a su creación y gestión.

En cuanto a las fuentes, que de manera técnica incluyen el manejo de indicadores de calidad de vida urbana con variables de espacio público, y que harán parte de la estructura propuesta, se revisaron los trabajos de Leva (2005); Hoornweg, Ruiz, Freire, Palugyai, Villaveces y Wills (2007), con el que los autores presentan una propuesta del Banco Mundial mediante la cual se busca establecer indicadores que permiten comparar a las ciudades en varias dimensiones; Páramo y Burbano (2013), en el que se crean indicadores para evaluar la habitabilidad del espacio público en Colombia; los indicadores estratégicos sectoriales de la Secretaría Distrital de Planeación de Bogotá; el listado de indicadores de espacio público de la Defensoría del Espacio Público (DADEP, s. f); y los indicadores de calidad de vida manejados por la organización Bogotá Cómo Vamos, revisiones a partir de las cuales se propone la estructura de indicadores para el espacio público en América Latina.

La estrategia para alcanzar el objetivo del estudio fue la investigación documental que se basa en el análisis metodológico y sistemático de datos, documentos escritos, fuentes de información impresas, contenidos y referencias bibliográficas (Uribe, 2011).

Por otra parte, se revisaron los aportes teóricos sobre el tema de indicadores de habitabilidad relacionados con el mejoramiento de calidad de vida, y, desde los antecedentes técnicos, se exploraron los diferentes indicadores de calidad de vida relacionados con el espacio público, 
aspectos estos que son tomados como punto de referencia para la conformación de una estructura de indicadores para los países de la región. A este respecto se revisan los trabajos de Leva (2005) y Páramo y Burbano (2013) principalmente. Desde el punto de vista teórico, el mayor aporte de estos autores está orientado a proponer la habitabilidad de los espacios públicos relacionada con la calidad de vida de los habitantes de las ciudades, y la necesidad de aportar desde el manejo de indicadores a la valoración de la habitabilidad de los espacios públicos. Otro aporte derivado de estos planteamientos está en que los respectivos instrumentos propuestos en sus investigaciones para valorar las condiciones que hacen habitable el espacio público han sido validados en ciudades latinoamericanas.

Para integrar los indicadores que hacen referencia directa a la habitabilidad del espacio público en una batería enmarcada en una estructura que permita valorar la habitabilidad de los espacios públicos en ciudades latinoamericanas de una manera efectiva, se hace necesario clasificarlos a partir de algunas categorías, de manera que permitan ubicarse dentro del aspecto específico que se quiere evaluar. Para ello, se revisaron propuestas que abarcan diferentes metodologías en el manejo de indicadores cuantitativos como es el caso de Leva (2005), Páramo y Burbano (2013) y el Banco Mundial (2007). Se revisaron además indicadores estratégicos sectoriales de la Secretaría Distrital de Planeación de Bogotá, y el listado de indicadores de espacio público de la Defensoría del Espacio Público (DADEP, s. f.), así como las seis variables tenidas en cuenta por el comparativo realizado por el estudio Bogotá 21. Se tomó el estudio de Wessels et al. (2012) titulado "Hacia una metrópoli de clase mundial orientada al transporte público". Por otra parte, se tuvieron en cuenta los temas que contempla la Encuesta Nacional de Calidad de Vida 2014 del DANE, Colombia, y los indicadores de calidad de vida manejados por la organización Red Colombiana de Ciudades Cómo Vamos (2014). Estos planteamientos elegidos para incluir indicadores de espacio público entre otros, fueron revisados y tomados como la línea base para plantear una propuesta general de categorización en la cual serán clasificados los indicadores de habitabilidad de espacio público.

En el caso de Leva (2005), se retomaron de las áreas propuestas aquellas que se pueden relacionar con espacio público, como: sostenibilidad ambiental, movilidad, servicios, dinámica cultural, seguridad, dinámica gubernamental, dinámicas sociales, economía y consumo, e infraestructura. Las áreas del estudio en mención que no se tuvieron en cuenta fueron las que no correspondían a indicadores aplicables al espa- cio público y estaban dirigidas a la valoración de calidad de vida desde la vivienda, los servicios públicos y su cobertura en la ciudad. En total se tomaron nueve áreas de este autor.

De la propuesta de indicadores subjetivos de Páramo y Burbano (2013) se retomaron las seis dimensiones tenidas en cuenta por los autores: comercio, medio ambiente, seguridad, servicios, cultura, infraestructura. Para el caso del trabajo de Hoornweg et al. (2007), se tomaron los indicadores que se recogen en dicho estudio (List of Habitat Agenda Indicators, WHO List of City Indicators, Unesco List of Indicators of racism and ethnic discrimination, European Foundation suggested indicators, Set of urban indicator susedby FCM), los cuales proponen varios listados de indicadores de los que, al ser analizados, se toman las dimensiones o categorías de: dinámicas ambientales, gubernamentales, sociales, económicas y de seguridad. En el benchmark realizado para el estudio Bogotá 21 (Wessels et al., 2012) se proponen seis criterios principales que cubren todo el campo de la calidad urbana y la habitabilidad, estos son: protección del medio ambiente, accesibilidad y función de distribución, factores suaves, infraestructura urbana, medio ambiente urbano, y seguridad y protección. El instrumento toma en cuenta un total de 74 aspectos que permiten evaluar el desempeño actual y potencial de las ciudades, de este estudio se tomaron las categorías de: infraestructura urbana, medio ambiente urbano, seguridad y protección, debido a que los otros tres están dirigidos a indicadores sociales de tipo generalizado hacia los usos y servicios de toda la ciudad.

La Secretaría Distrital de Planeación de Bogotá (2012), en el documento de implementación del Sistema de Información Integral para la Planeación del Distrito (SIIPD), plantea quince dimensiones por medio de las cuales se puede hacer la evaluación de la calidad de vida urbana. Sin embargo, estas dimensiones están distribuidas entre cinco principales, en las cuales están clasificados todos los indicadores disponibles en el SIIPD, que son: ambiental, social, económica, cultural y territorial, de las cuales se tienen en cuenta las primeras cuatro. De estas dimensiones se eligieron aquellos indicadores aplicables a la valoración de la habitabilidad, relacionadas con el espacio público. Se revisó también el Sistema Estadístico Nacional (SEN) (DANE, 2015), el cual maneja tres caracterizaciones temáticas: económicas, sociales y medioambientales, que describen los atributos relacionados con la producción y organización estadística, la cual cuenta con veinte temas generales que contienen los indicadores, los temas elegidos son: ambientales, comercio, cultura, gobierno, seguridad y defensa, tecnología e innovación. Finalmente, Bogotá Cómo Vamos (2014), en su informe de calidad de vida del mismo año, 
maneja 14 áreas que contienen los indicadores implementados en sus respectivos estudios y propuestas, de dicho listado se retoman: espacio público, medio ambiente, gestión pública, movilidad, cultura, recreación y deporte.

\section{Resultados}

A partir de la revisión de las distintas fuentes de indicadores se propone finalmente un listado de categorías en las cuales son agrupados los respectivos indicadores, teniendo en cuenta lo que cada área o dimensión tendría como objetivo para la evaluación del espacio público.
Estas categorías son: sostenibilidad ambiental, movilidad y accesibilidad, servicios, dinámicas culturales, gubernamentales, sociales, economía y consumo, infraestructura, y seguridad y protección.

A continuación se señalan los objetivos principales de cada categoría y, con base en estos, se relacionarán más adelante los indicadores identificados con el fin de proponer la batería de indicadores por categorías que permitan valorar la habitabilidad de los espacios públicos en ciudades latinoamericanas. La Tabla 1 y Figura 1 dan cuenta de las categorías propuestas, junto con los objetivos que perseguiría cada una.
Sostenibilidad ambiental

Movilidad y accesibilidad

Servicios

Dinámica cultural

Dinámica gubernamental

Dinámicas sociales

Estímulos al fomento de las relaciones sociales y la participación de los individuos
Acciones dirigidas a garantizar la calidad ambiental

Desplazamiento de los usuarios dentro y hacia el espacio público y accesibilidad al mismo
Disponibilidad de propuestas culturales

Propuestas impulsadas por el Gobierno en función de la intervención de los espacios públicos

Economía y consumo La forma y los medios en que se satisfacen necesidades humanas de consumo

Infraestructura

Oferta y estado de la infraestructura disponible como soporte al desarrollo de actividades y funcionamiento del espacio público

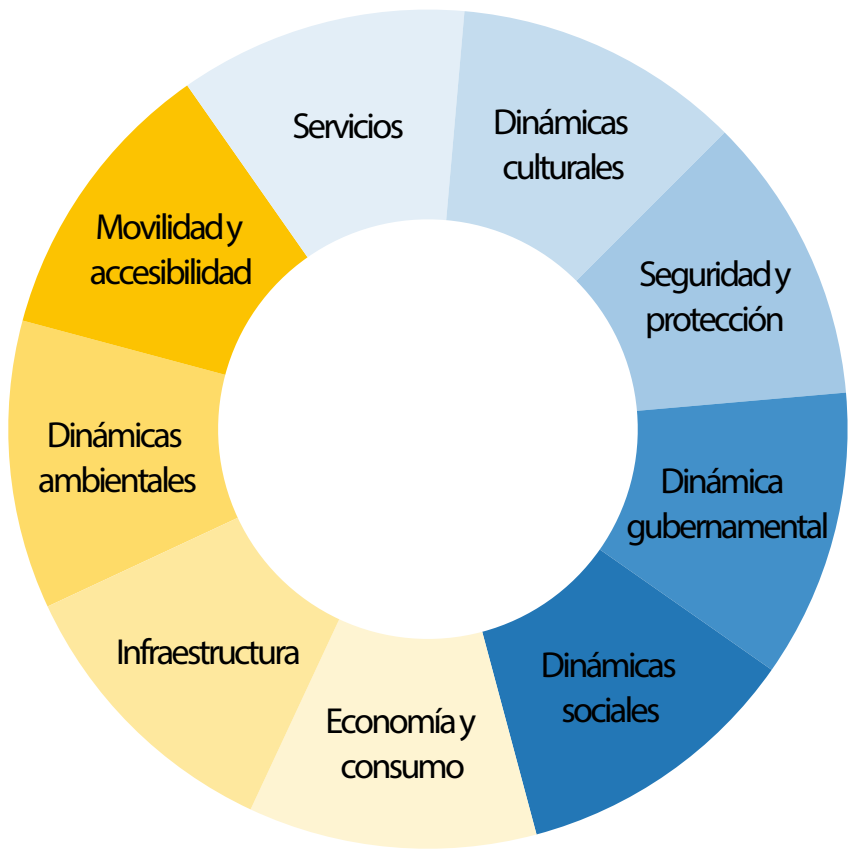

Figura 1. Propuesta de categorización para la clasificación de indicadores de habitabilidad del espacio público Fuente: elaboración propia. 
Propuesta de una estructura que agrupa baterías de indicadores, dirigida a valorar la habitabilidad de los espacios públicos en ciudades latinoamericanas

A partir de las categorías propuestas anteriormente se presenta la estructura que agrupa las distintas baterías de indicadores. Dentro de cada categoría se presenta la batería de indicadores que la conforman, la medición que se tiene de cada uno de ellos, su clasificación en términos de si se trata de un indicador objetivo y subjetivo $y$, finalmente, la fuente del indicador. Las siguientes tablas desarrollan la propuesta.

Listado de la clasificación de indicadores por categorías:

\begin{tabular}{|c|c|c|c|c|}
\hline Categoría & Indicador & Fórmula & Tipo & Fuente del indicador \\
\hline \multirow{21}{*}{ 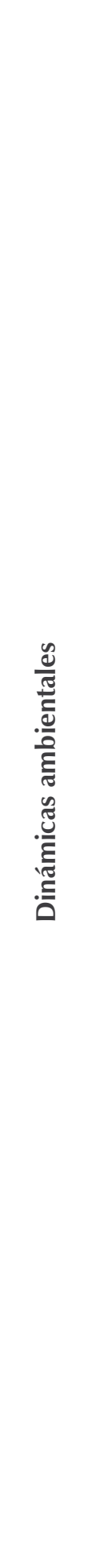 } & Calidad del agua en ríos urbanos & Nivel de contaminación hídrica & \multirow{10}{*}{$\frac{\stackrel{0}{0}}{\frac{0}{0}}$} & Bogotá cómo vamos (2014) \\
\hline & Reciclaje & Porcentaje de la basura total que es reciclada & & Bogotá cómo vamos (2014) \\
\hline & Árboles por hectárea & $\begin{array}{l}\text { Número de individuos por hectárea en el espacio } \\
\text { público }\end{array}$ & & JBJCM (2013) \\
\hline & Árboles por habitante & Número de individuos por habitantes & & JBJCM (2013) \\
\hline & Área de suelo de protección & $\begin{array}{l}\text { Área de reserva o protección no urbanizable/área } \\
\text { total del espacio público }\end{array}$ & & $\begin{array}{l}\text { Observatorio ambiental de } \\
\text { Bogotá D.C. (s. f) }\end{array}$ \\
\hline & $\begin{array}{l}\text { Espacios verdes públicos por } \\
\text { habitantes }\end{array}$ & $\begin{array}{l}\text { Jardines y espacios verdes públicos y privados de } \\
\text { acceso público por habitante }\left(\mathrm{m}^{2} / \mathrm{hab}\right)\end{array}$ & & Leva (2005) \\
\hline & Confort acústico & $\begin{array}{l}\text { Cacústico }(\%)=(\text { población con afectación sonora } \\
\text { diurna inferior a } 65 \mathrm{~dB} 8 \mathrm{~A}) / \text { población total })\end{array}$ & & DADEP (2013) \\
\hline & Índice de calidad del aire & $\begin{array}{l}\mathrm{C} \text { aire }(\%)=(\text { población expuesta a niveles de } \\
\text { inmisión de } \mathrm{NO}_{2} \text { y PM10 inferiores a } 40 \mathrm{ug} / \mathrm{m}^{3} / \\
\text { población total) }\end{array}$ & & DADEP (2013) \\
\hline & $\begin{array}{l}\text { Estructura ecológica principal } \\
\text { restaurada, recuperada o } \\
\text { rehabilitada }\end{array}$ & $\begin{array}{l}\text { Recuperación estructura ecológica principal; número } \\
\text { de hectáreas restauradas, recuperadas o rehabilitadas } \\
\text { en áreas de estructura ecológica principal }\end{array}$ & & DADEP (2013) \\
\hline & Área de jardines verticales & $\mathrm{m}^{2} /$ total EP & & $\begin{array}{l}\text { Observatorio ambiental de } \\
\text { Bogotá D.C. (s. f) }\end{array}$ \\
\hline & Residuos sólidos urbanos reciclados & $\begin{array}{l}\text { Recolección especial de papel, vidrio, madera, } \\
\text { residuos verdes, que son objeto de reciclado }\end{array}$ & \multirow{11}{*}{ 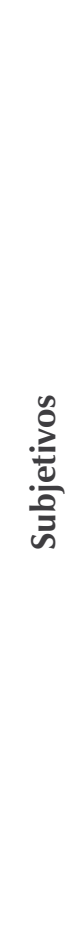 } & Leva (2005) \\
\hline & Elementos naturales & $\begin{array}{l}\text { La presencia de elementos naturales (plantas, } \\
\text { árboles, fauna) }\end{array}$ & & Páramo y Burbano (2013) \\
\hline & Cambios climáticos & $\begin{array}{l}\text { Que puede uno protegerse de los cambios climáticos } \\
\text { (exceso de calor o lluvia) }\end{array}$ & & Páramo y Burbano (2013) \\
\hline & El clima predominante de la ciudad & Favorece o no el disfrute del espacio público & & Páramo y Burbano (2013) \\
\hline & Esmog & $\begin{array}{l}\text { El esmog o polución atmosférica que se percibe } \\
\text { actualmente en la ciudad }\end{array}$ & & Páramo y Burbano (2013) \\
\hline & La publicidad visual exterior & Presencia de publicidad visual exterior & & Páramo y Burbano (2013) \\
\hline & Mantenimiento de las zonas verdes & $\begin{array}{l}\text { Corte de prado, mantenimiento de jardines, poda de } \\
\text { arborización }\end{array}$ & & Propuesta propia \\
\hline & La publicidad auditiva exterior & & & Páramo y Burbano (2013) \\
\hline & $\begin{array}{l}\text { Que esté libre del humo de } \\
\text { fumadores }\end{array}$ & & & Páramo y Burbano (2013) \\
\hline & Presencia de vectores animales & Roedores, plagas en general & & Propio \\
\hline & Libre de malos olores & & & Páramo y Burbano (2013) \\
\hline
\end{tabular}

(4) Tabla 2. Categoría 1: dinámicas ambientales

Fuente: elaboración propia.

Esta categoría contempla 21 indicadores, correspondientes al $24 \%$ del total de indicadores, de los cuales 10 son objetivos y 11 subjetivos, estando muy equilibrados en cantidad dentro de las dos categorías (Tabla 2). 


\begin{tabular}{|c|c|c|c|c|}
\hline Categoría & Indicador & Observaciones & Tipo & $\begin{array}{l}\text { Fuente teórica } \\
\text { del indicador }\end{array}$ \\
\hline \multirow{11}{*}{ 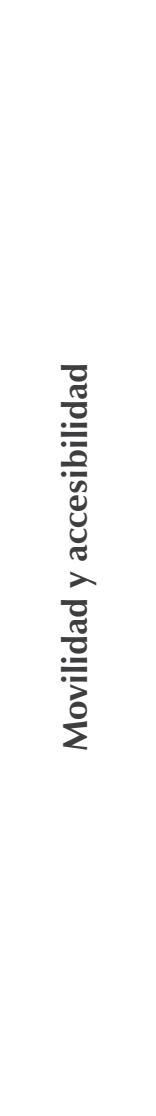 } & $\begin{array}{l}\text { Lugares disponibles en parques } \\
\text { de estacionamiento }\end{array}$ & Plazas de parqueo $/ \mathrm{m}^{2}$ & \multirow{6}{*}{$\frac{\stackrel{n}{0}}{\frac{2}{2}}$} & Leva (2005) \\
\hline & Libre de obstáculos al peatón & $\begin{array}{l}\text { Cantidad promedio de obstáculos al } \\
\text { peatón cada } 100 \mathrm{~m}\end{array}$ & & Leva (2005) \\
\hline & $\begin{array}{l}\text { Distancia promedio para } \\
\text { acceder al transporte público }\end{array}$ & 100 a $200 \mathrm{~m}$ & & Propio \\
\hline & \multirow[b]{2}{*}{ Ciclorrutas existentes } & Porcentaje de cobertura de las ciclorrutas & & Bogotá cómo vamos (2014) \\
\hline & & km de ciclovía construida & & $\begin{array}{l}\text { Observatorio ambiental de } \\
\text { Bogotá D.C. (s.f) }\end{array}$ \\
\hline & $\begin{array}{l}\text { Accesibilidad a los espacios } \\
\text { públicos desde mi lugar de } \\
\text { vivienda }\end{array}$ & 10 min caminando-300 m distancia & & DADEP (2013). \\
\hline & El estado de la malla vial & Estado actual & \multirow{5}{*}{ 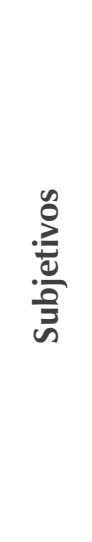 } & Páramo y Burbano (2013) \\
\hline & $\begin{array}{l}\text { Accesibilidad a los espacios } \\
\text { públicos desde los medios de } \\
\text { transporte }\end{array}$ & $\begin{array}{l}\text { Distancia promedio en relación con } \\
\text { el transporte público }\end{array}$ & & Páramo y Burbano (2013) \\
\hline & $\begin{array}{l}\text { Ciclovía los domingos y días } \\
\text { festivos }\end{array}$ & $\begin{array}{l}\text { Infraestructura adecuada para el uso seguro de la } \\
\text { bicicleta domingos y festivos }\end{array}$ & & Páramo y Burbano (2013) \\
\hline & Rampas & $\begin{array}{l}\text { Rampas que faciliten el desplazamiento de coches para } \\
\text { bebes o personas con discapacidad física }\end{array}$ & & Páramo y Burbano (2013) \\
\hline & $\begin{array}{l}\text { Zonas peatonales que existen } \\
\text { actualmente }\end{array}$ & $\begin{array}{l}\text { Condiciones peatonales disponibles } \\
\text { en el espacio público }\end{array}$ & & Páramo y Burbano (2013) \\
\hline
\end{tabular}

(A) Tabla 3. Categoría 2: movilidad y accesibilidad

Fuente: elaboración propia.

En esta categoría se relacionaron 10 indicadores, correspondientes al $10 \%$ del total de la batería, 5 de ellos son objetivos y 5 son subjetivos, otra relación equilibrada entre las 2 categorías (Tabla 3 ).

\begin{tabular}{|c|c|c|c|c|}
\hline Categoría & Indicador & Observaciones & Tipo & $\begin{array}{l}\text { Fuente teórica } \\
\text { del indicador }\end{array}$ \\
\hline \multirow{12}{*}{$\frac{n}{\frac{0}{u}}$} & Espacios deportivos existentes & Instalaciones deportivas por habitantes & \multirow{2}{*}{$\frac{\substack{0 \\
\frac{0}{0}}}{0}$} & Bogotá cómo vamos (2014) \\
\hline & $\begin{array}{l}\text { Cobertura en la recolección de } \\
\text { residuos sólidos }\end{array}$ & Área de cobertura \% sobre total de $\mathrm{m}^{2}$ & & Secretaría de Planeación Distrital \\
\hline & $\begin{array}{l}\text { Cajeros automáticos de las } \\
\text { corporaciones bancarias }\end{array}$ & Existencia de cajeros & \multirow{10}{*}{$\frac{\stackrel{n}{0}}{\frac{0}{\frac{0}{2}}}$} & Páramo y Burbano (2013) \\
\hline & Señalización & Tránsito, mapas, etc. & & Páramo y Burbano (2013) \\
\hline & Que sea para todos & Niños, jóvenes, adultos mayores & & Páramo y Burbano (2013) \\
\hline & $\begin{array}{l}\text { Calidad y ubicación de los baños } \\
\text { públicos }\end{array}$ & Existencia, calidad, cantidad y ubicación & & Páramo y Burbano (2013) \\
\hline & Múltiples actividades & Oportunidad de desarrollar múltiples actividades & & Páramo y Burbano (2013) \\
\hline & $\begin{array}{l}\text { Disponibilidad de lugares de } \\
\text { recreación para niños }\end{array}$ & Oferta de servicios para niños & & Páramo y Burbano (2013) \\
\hline & $\begin{array}{l}\text { Disponibilidad de lugares de } \\
\text { encuentro para los jóvenes }\end{array}$ & Oferta de servicios para jóvenes & & Páramo y Burbano (2013) \\
\hline & Mascotas & Permiso para acceso a mascotas & & Propuesta propia \\
\hline & Disponibilidad de agua potable & Acceso a agua potable gratuita & & Propuesta propia \\
\hline & $\begin{array}{l}\text { Estado de aseo en que se } \\
\text { encuentra el EP }\end{array}$ & Limpieza y mantenimiento del espacio público & & Páramo y Burbano (2013) \\
\hline
\end{tabular}

(A) Tabla 4. Categoría 3: servicios

Fuente: elaboración propia, 2015.

En esta categoría fueron relacionados 13 indicadores correspondientes al $13 \%$ del total de la batería propuesta, 3 de ellos son objetivos y 10 son subjetivos, en esta categoría predominan los indicadores subjetivos (Tabla 4). 


\begin{tabular}{|c|c|c|c|}
\hline $\begin{array}{l}\text { Áreas clasificadas como } \\
\text { "patrimonio mundial de la } \\
\text { humanidad" }\end{array}$ & Área clasificada por la Unesco $\left(\mathrm{km}^{2}\right)$ & $\frac{\stackrel{d}{0}}{\frac{0}{0}}$ & Leva (2005) \\
\hline Elementos culturales & $\begin{array}{l}\text { Esculturas, monumentos, } \\
\text { obras de arte }\end{array}$ & \multirow{5}{*}{ 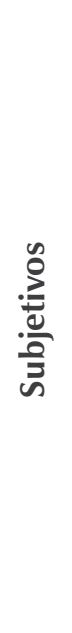 } & Páramo y Burbano (2013) \\
\hline Actividades culturales gratuitas & $\begin{array}{l}\text { Desfiles o conciertos que se realizan en } \\
\text { la ciudad para el público general }\end{array}$ & & Páramo y Burbano (2013) \\
\hline $\begin{array}{l}\text { Identidad de los espacios } \\
\text { públicos }\end{array}$ & Que se pueda diferenciar de los demás & & Páramo y Burbano (2013) \\
\hline $\begin{array}{l}\text { Monumentos declarados de } \\
\text { interés público }\end{array}$ & $\begin{array}{l}\text { Con declaratoria de interés nacional o } \\
\text { provincial }\end{array}$ & & Leva (2005) \\
\hline Funciones espectáculos culturales & $\begin{array}{l}\text { Oferta de espectáculos culturales } \\
\text { públicos }\end{array}$ & & Leva (2005) \\
\hline
\end{tabular}

(A) Tabla 5. Categoría 4: dinámicas culturales

Fuente: elaboración propia.

En esta categoría se relacionaron 6 indicadores, correspondientes al $7 \%$ del total de la batería propuesta, solo 1 es objetivo y los 5 restantes son subjetivos, una categoría más donde los subjetivos dominan (Tabla 5).

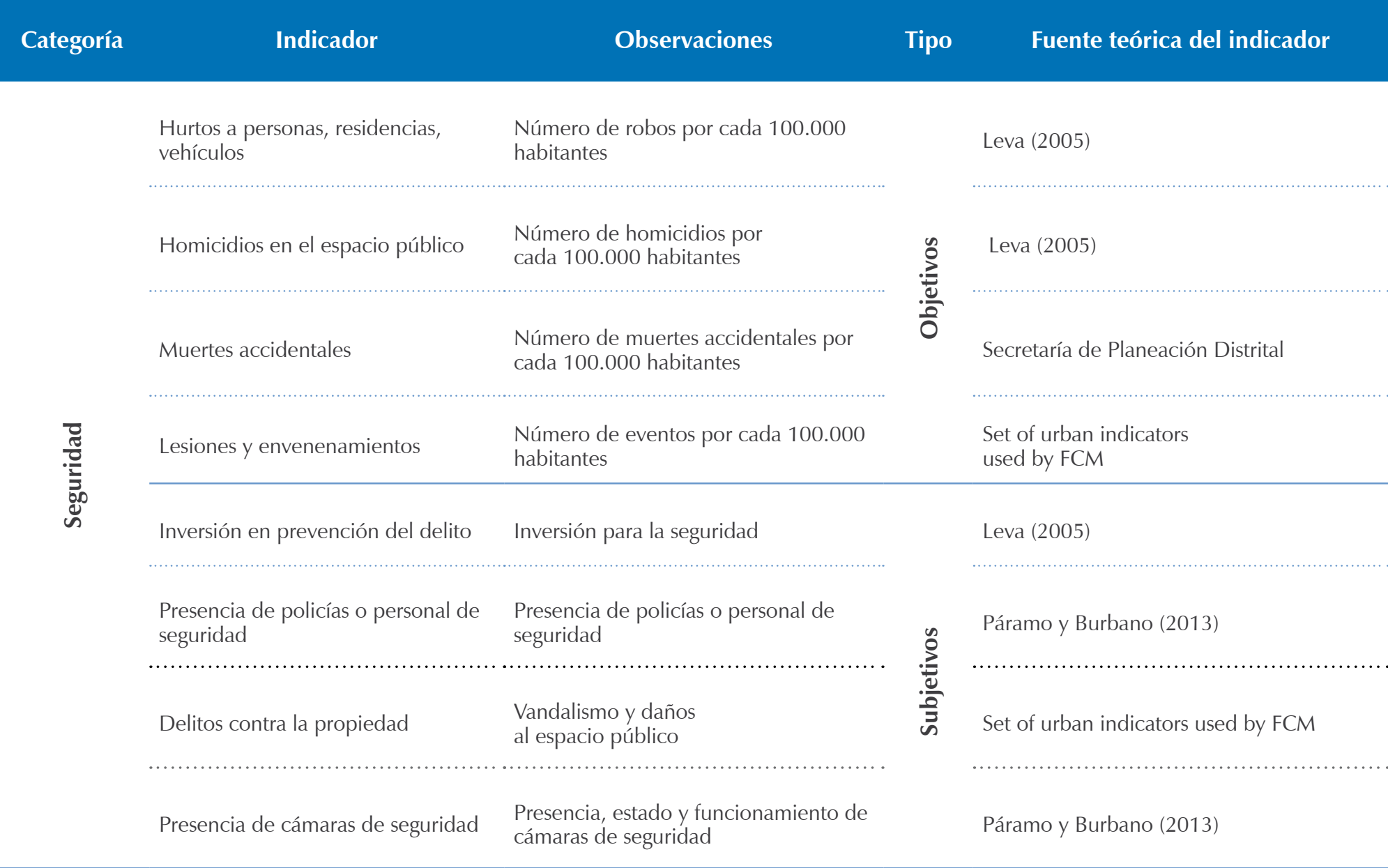

(4) Tabla 6. Categoría 5: seguridad

Fuente: elaboración propia.

En esta categoría se relacionaron 8 indicadores correspondientes al $9 \%$ del total propuesto en la batería de indicadores; los indicadores objetivos y subjetivos están totalmente equilibrados al $50 \%$ cada uno (Tabla 6). 


\begin{tabular}{|c|c|c|c|c|}
\hline Categoría & Indicador & Observaciones & Tipo & Fuente teórica del indicador \\
\hline \multirow{4}{*}{ 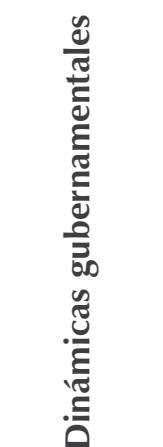 } & Espacio público recuperado & $\begin{array}{l}M^{2} \text { de espacio público recuperado de invasión al } \\
\text { espacio pub/total de EP }\end{array}$ & \multirow{3}{*}{$\frac{\mathscr{2}}{\stackrel{0}{0}} \frac{0}{0}$} & Secretaría de Planeación Distrital \\
\hline & $\begin{array}{l}\text { Aprovechamiento } \\
\text { económico }\end{array}$ & $\begin{array}{l}\text { Espacio administrado que genera } \\
\text { aprovechamiento económico }\left(\mathrm{m}^{2}\right)\end{array}$ & & $\begin{array}{l}\text { Departamento Administrativo Distrital } \\
\text { del Espacio Público (DADEP) }\end{array}$ \\
\hline & Espacio público recalificado & $\begin{array}{l}\text { Áreas que fueron objeto de intervención y } \\
\text { puesta en valor o recalificación }\left(\mathrm{m}^{2}\right)\end{array}$ & & Leva (2005) \\
\hline & $\begin{array}{l}\text { Proyectos gestionados por } \\
\text { la comunidad }\end{array}$ & Procesos comunitarios & $\stackrel{0}{\bar{b}}$ & Leva (2005) \\
\hline
\end{tabular}

(A) Tabla 7. Categoría 6: dinámicas gubernamentales

Fuente: elaboración propia.

En la categoría de dinámicas gubernamentales se relacionaron 4 indicadores, correspondientes al 4,5\% del total de la batería propuesta, 3 de ellos son objetivos y uno subjetivo. Es la categoría donde menos indicadores subjetivos se relacionan (Tabla 7).

\begin{tabular}{|c|c|c|c|c|}
\hline Categoría & Indicador & Observaciones & Tipo & $\begin{array}{l}\text { Fuente teórica del } \\
\text { indicador }\end{array}$ \\
\hline \multirow{16}{*}{ 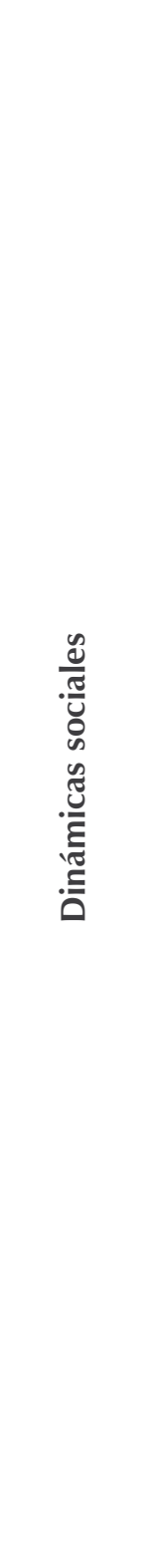 } & Normas de tránsito & Respeto que se observa por las normas de tránsito & \multirow{16}{*}{$\frac{\mathscr{n}}{\frac{0}{\frac{d}{2}}}$} & Páramo y Burbano (2013) \\
\hline & $\begin{array}{l}\text { Posibilidad de realizar } \\
\text { manifestaciones religiosas/políticas/ } \\
\text { artísticas }\end{array}$ & $\begin{array}{l}\text { Facilita realizar manifestaciones religiosas/políticas/ } \\
\text { artísticas }\end{array}$ & & Páramo y Burbano (2013) \\
\hline & $\begin{array}{l}\text { Grado de constitución de espacios } \\
\text { formales para la participación }\end{array}$ & Facilita y promueve la participación & & $\begin{array}{l}\text { Secretaría de Planeación } \\
\text { Distrital }\end{array}$ \\
\hline & $\begin{array}{l}\text { Presencia de trabajadoras sexuales } \\
\text { en las calles }\end{array}$ & Presencia de trabajadoras sexuales en las calles & & Páramo y Burbano (2013) \\
\hline & $\begin{array}{l}\text { Población sin alojamiento ni medios } \\
\text { de subsistencia }\end{array}$ & Presencia de indigentes & & Leva (2005) \\
\hline & Instrumentos musicales & Presencia de instrumentos musicales & & Páramo y Burbano (2013) \\
\hline & Equitativo para todos los géneros & Promueve el uso equitativo para todos los géneros & & Páramo y Burbano (2013) \\
\hline & Músicos en la calle & Presencia de músicos en la calle & & Páramo y Burbano (2013) \\
\hline & $\begin{array}{l}\text { Presencia de malabaristas en los } \\
\text { semáforos }\end{array}$ & Presencia de malabaristas en los semáforos & & Páramo y Burbano (2013) \\
\hline & $\begin{array}{l}\text { Diversidad de lo que pueda } \\
\text { observarse o experimentarse }\end{array}$ & $\begin{array}{l}\text { Diversidad de: usos, visuales, actividades y } \\
\text { posibilidades recreativas }\end{array}$ & & Páramo y Burbano (2013) \\
\hline & $\begin{array}{l}\text { Grafitis o pinturas en los muros de } \\
\text { la ciudad }\end{array}$ & Presencia de grafitis o pinturas en el espacio público & & Páramo y Burbano (2013) \\
\hline & Contacto social & $\begin{array}{l}\text { Posibilidad de entrar en contacto social con otras } \\
\text { personas }\end{array}$ & & Páramo y Burbano (2013) \\
\hline & Reglas de convivencia & Respeto por las reglas de convivencia & & Páramo y Burbano (2013) \\
\hline & Desplazados & Presencia de desplazados & & Páramo y Burbano (2013) \\
\hline & Excretas en el espacio público & Excretas animales y humanas en el espacio público & & $\begin{array}{l}\text { Andrés Arévalo } \\
\text { (comunicación personal) }\end{array}$ \\
\hline & Población con adicciones & $\begin{array}{l}\text { Presencia de drogadictos y alcohólicos en el espacio } \\
\text { público }\end{array}$ & & Leva (2005) \\
\hline
\end{tabular}

(A) Tabla 8. Categoría 7: dinámicas sociales

Fuente: elaboración propia, 2015.

En esta categoría se relacionan 16 indicadores correspondientes al $17 \%$ del total de la batería, todos los indicadores relacionados con esta categoría son subjetivos (Tabla 8). 


\begin{tabular}{l} 
Comercio formal \\
Comercio o ventas \\
informales callejeras \\
\hline Aprovechamiento \\
económico
\end{tabular}

$\mathrm{M}^{2}$ de zona comercial planificado sobre el espacio público

Número de vendedores ambulantes en el espacio público

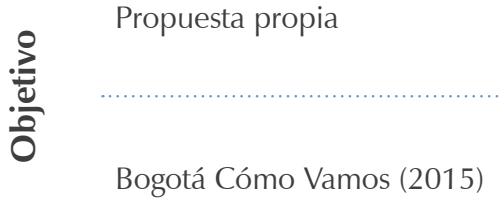

Leva (2005)

(4) Tabla 9. Categoría 8: economía y consumo

Fuente: elaboración propia, 2015.

Esta categoría solo relaciona 3 indicadores correspondientes al $3 \%$ del total, uno es subjetivo y 2 son objetivos (Tabla 9).

\begin{tabular}{|c|}
\hline Categoría \\
\hline
\end{tabular}

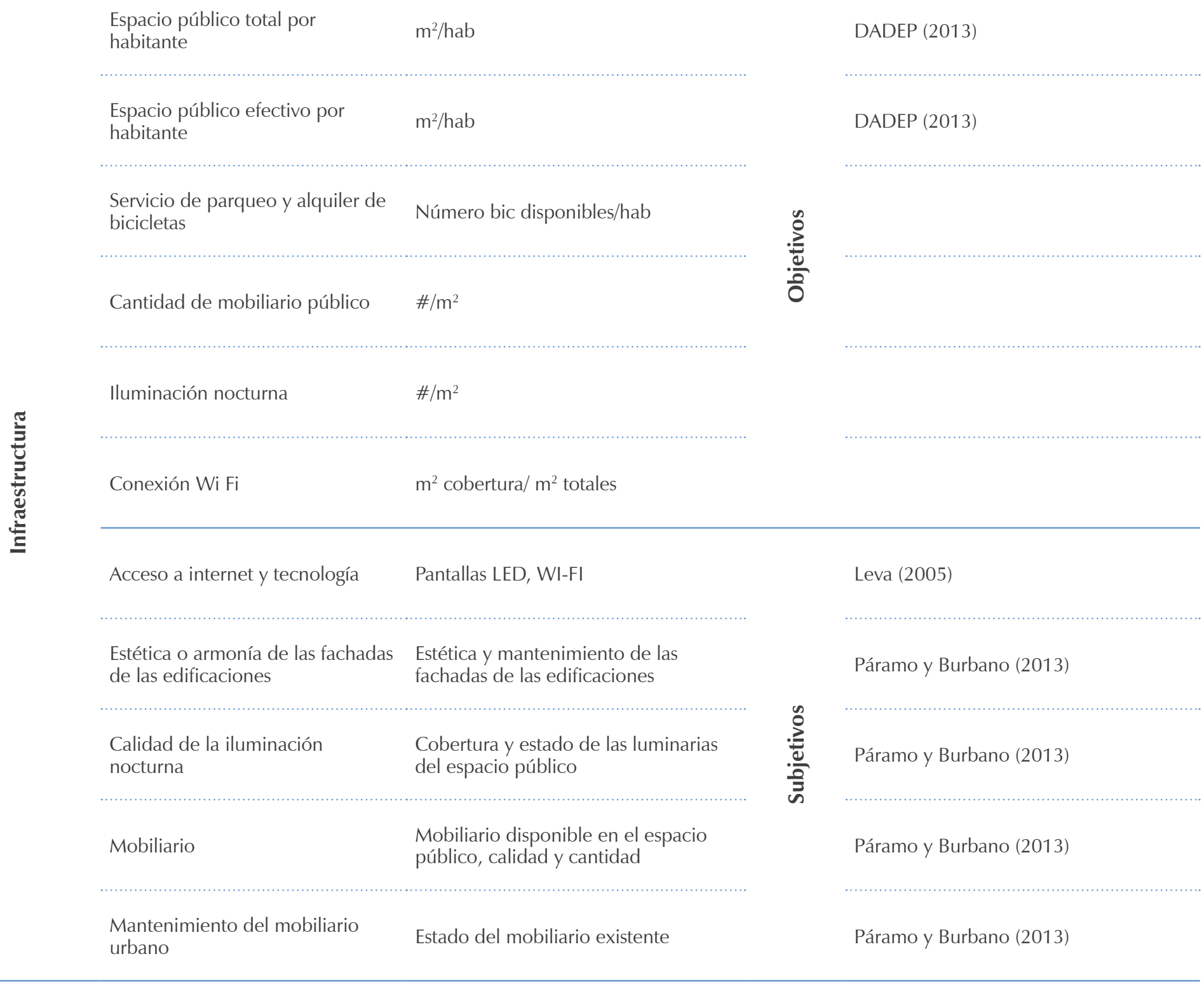

(A) Tabla 10. Categoría 9: infraestructura

Fuente: elaboración propia, 2015.

En esta categoría se relacionan 11 indicadores correspondientes al $10 \%$ del total de la batería propuesta, son muy equilibrados en cuanto a cantidad (Tabla 10). 
Indicadores objetivos y subjetivos por categoría

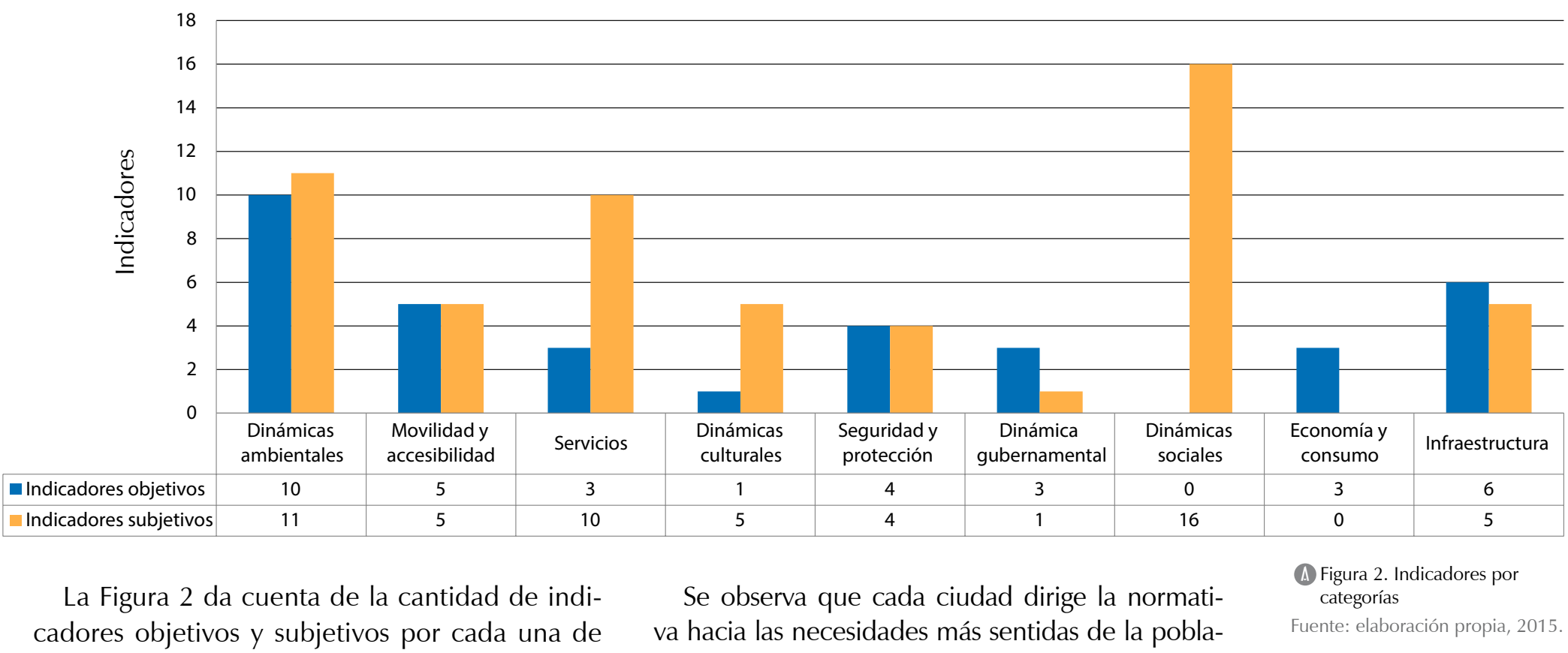

las categorías establecidas.

\section{Análisis de los indicadores dentro de la norma urbana latinoamericana}

Con base en la batería de indicadores propuesta por categorías, se realizó una revisión normativa sobre las ciudades que fueron tomadas como referentes de la calidad del espacio público en Latinoamérica. El estudio de la norma relacionada con el espacio público en estas ciudades arrojó una serie de resultados que, al ser interpretados en conjunto, evidencian la necesidad de incluir una propuesta que promueva la valoración de los espacios públicos en términos de su habitabilidad. A continuación se exponen los resultados de la mencionada revisión.

A nivel general se evidencian varias tendencias entre las ciudades de estudio, la primera y predominante es el direccionamiento de las políticas hacia el reconocimiento de los conceptos generales del espacio público y sus componentes. La normativa se enfoca en caracterizar los espacios públicos definiéndolos y clasificándolos, como primer paso de reconocimiento a la valoración que se presenta; sin embargo, los indicadores de espacio público, habitabilidad y calidad de vida urbana no son tenidos en cuenta dentro de los planteamientos, ya que la norma se refiere principalmente a la contextualización e información del espacio público en términos generales, y no da recomendaciones sobre su uso. La segunda tendencia se evidencia en los casos en que se pasa del reconocimiento y la apreciación a dar directrices concretas sobre una problemática específica, como el caso del comercio o las ventas informales callejeras, que es el indicador que como tema se ve más manejado en catorce ciudades, cuatro de ellas lo tienen en cuenta, pero no como punto de referencia cuantitativo, sino como referencia cualitativa hacia el cumplimiento de los objetivos de la norma. va hacia las necesidades más sentidas de la población. En los contenidos de la norma es claro el direccionamiento hacia al manejo de problemas muy particulares de las ciudades, un ejemplo es el comercio informal relacionado con la invasión del espacio público, que además de ser un asunto que se desarrolla en dicho espacio, tiene consecuencias económicas y sociales sobre la ciudad, lo cual hace que esto sea tratado más allá de un problema del espacio público y se maneje de forma trasversal a diferentes temas (económico, social, espacial, etc.); tal manejo transversal también influye en que el tema sea priorizado debido a su urgencia, y se le dé ventaja sobre los problemas del espacio público que se refieren a un único tema. En el caso específico del espacio público, los indicadores relacionados con el comercio informal y la invasión son: comercio o ventas informales callejeras, y venta de bebidas y alimentos, que hacen parte de la categoría de economía y consumo, entendida como la categoría de mayor uso en la normativa definida como insumo.

En el momento de realizar un reconocimiento general de la norma, se pueden establecer características predominantes de la problemática relacionada con el espacio público en cada una de las ciudades, de una manera casi evidente. Se demuestra por qué es en esos temas específicos que se centra la norma; y la manera en que mediante esta se da respuesta a dicha problemática en coherencia con la política pública.

Después de clasificar y analizar las normas identificadas por país de acuerdo con los indicadores propuestos, se pudo determinar cómo cada ciudad profundiza la norma en temas puntuales como el caso de São Paulo en Brasil, que encamina la norma al mantenimiento de la malla vial y peatonal, a su conservación y a determinar responsables de las acciones que se establecen en los espacios públicos; plantea directrices para los espacios públicos y recreativos, así como las pautas para su uso; se enfoca en liberar espacio público de parqueos y 
mobiliario no regulado. La normativa se centra en recuperar espacios por medio de la prohibición de parqueos, la regulación del comercio y la renovación de aceras y muros de la ciudad, e incorpora la seguridad y la limpieza de manera imperante. Los mecanismos predominantes para la regulación son: el establecimiento de responsabilidades en las intervenciones y el manejo del espacio público por medio de directrices en las políticas públicas. La Figura 3 muestra los indicadores incluidos (no se incluyen de manera textual, aunque es lo que se propone a futuro):

En Rio de Janeiro, Brasil, el centro de su normativa está enfocado en las directrices sobre el sistema de transporte y la regularización de las actividades realizadas en el espacio público, como los masajes. Plantea directrices generales sobre el sistema de transporte y el sistema vial a manera de regulación. Busca homogeneizar las zonas públicas ocupadas por el comercio, regula la prestación de masajes y terapias corporales en las áreas de servicio público, da las directrices para la organización en el manejo de los anuncios. En la Figura 4 se muestran los indicadores que se identifican dentro de su normativa.

Belo Horizonte, Brasil, se centra en las disposiciones generales para el desarrollo urbano de la ciudad como: implementación de ciclovías y el establecimiento del sistema viario de la ciudad. Los mecanismos que establecen son las directrices para el manejo del sistema vial y la promoción de nuevas prácticas del planeamiento y uso de ciclovías, como se muestra en la Figura 5.
Porto Alegre, Brasil, fomenta la preservación de sus zonas verdes buscando la medida justa en doce metros cuadrados por habitante. Es de las pocas que maneja un indicador objetivo desde el punto de vista de lo ideal, y no para la solución del problema inmediato. Manejan política de desarrollo urbano y medio ambiente, así como política ambiental; los indicadores objetivos son los mecanismos para la regulación. El único indicador manejado es el espacio verde público por habitante.

Ciudad de México centra sus políticas en la conservación, recuperación y acrecentamiento del patrimonio cultural de la ciudad, integración de los inmuebles y sus fachadas al contexto, y ordenamiento territorial del patrimonio cultural urbano. Los mecanismos que establecen son el establecimiento de responsables en el manejo de la conservación del patrimonio, la identificación del mismo y la regulación en el tema de la publicidad y el manejo del contexto.

En Puebla, México, la norma que se maneja está basada en la regulación de los programas generales requeridos para el desarrollo urbano, en estos se incluyen definiciones de espacio público y sus componentes de una manera muy general, los tres indicadores que se relacionan según el tema se muestran en la Figura 6.

En Puebla no hay evidencia de normativa relacionada con indicadores de espacio público.

En Guadalajara, México, la norma está enfocada en recuperar espacios públicos con deterioro, abandono o inseguridad; como mecanismo para

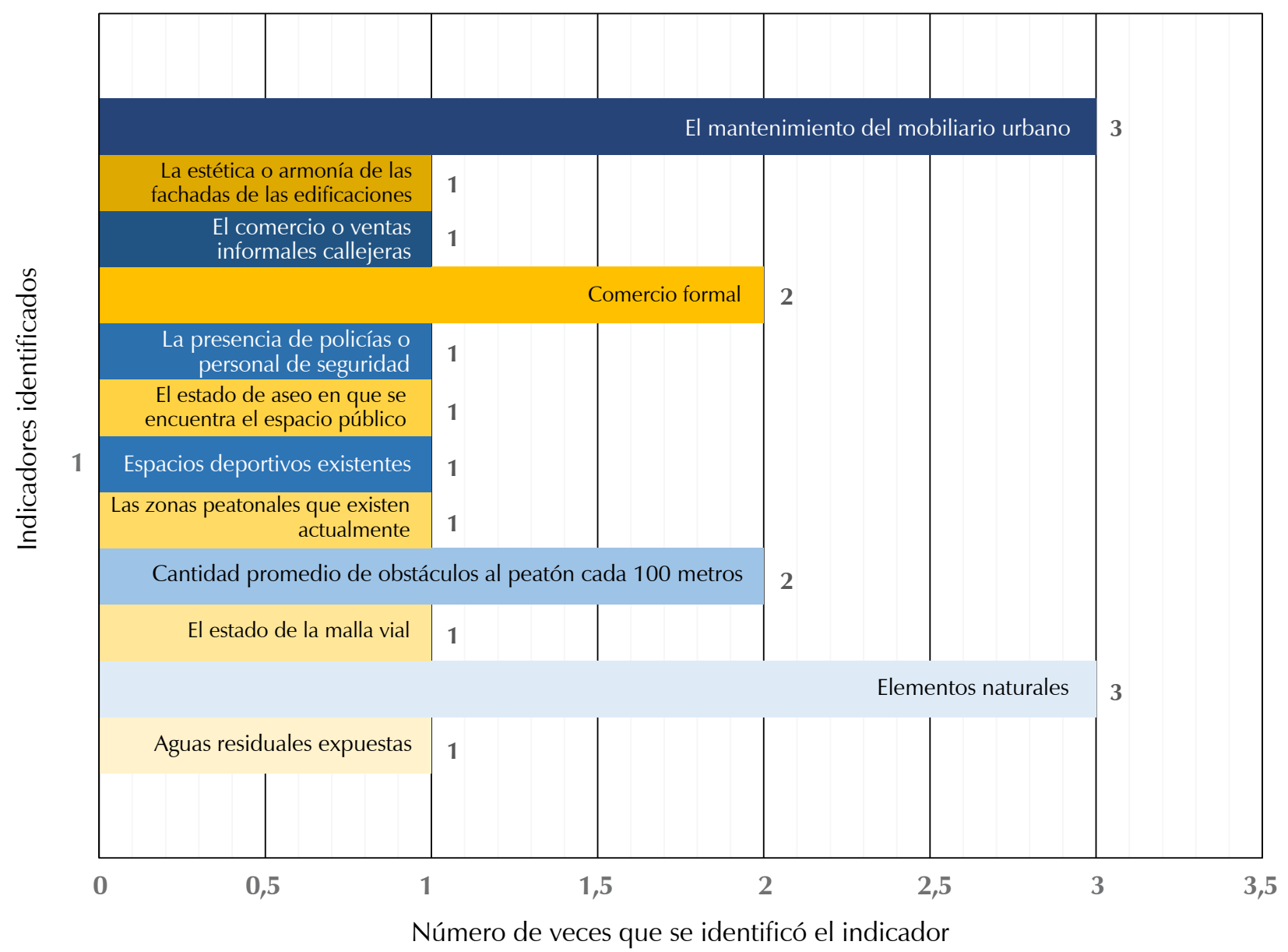


la regulación asigna recursos para la intervención en los mismos. Como tema relacionado con el indicador se identifican los espacios públicos recalificados.

En Quito, Ecuador, las políticas públicas están orientadas a los servicios públicos y la participación ciudadana, se manejan de forma general sobre la organización del territorio. La clasificación del espectáculo público es la única política que se evidencia en cuanto a espacio público y se maneja como ordenanza de obligatorio cumplimiento.
En Loja, Ecuador, la norma define y caracteriza la señalética, y especifica el cuidado del ornato de las edificaciones y los espacios públicos fomentando la calidad ambiental y evitando la contaminación visual. Los mecanismos de regulación son prohibiciones para el caso del mobiliario urbano que no cumple las especificaciones, y multas para la mala ubicación del mobiliario urbano, ordenanza de regulación. Los dos temas relacionados con indicadores se muestran en la Figura 7.

Indicadores identificados en Rio de Janeiro, Brasil

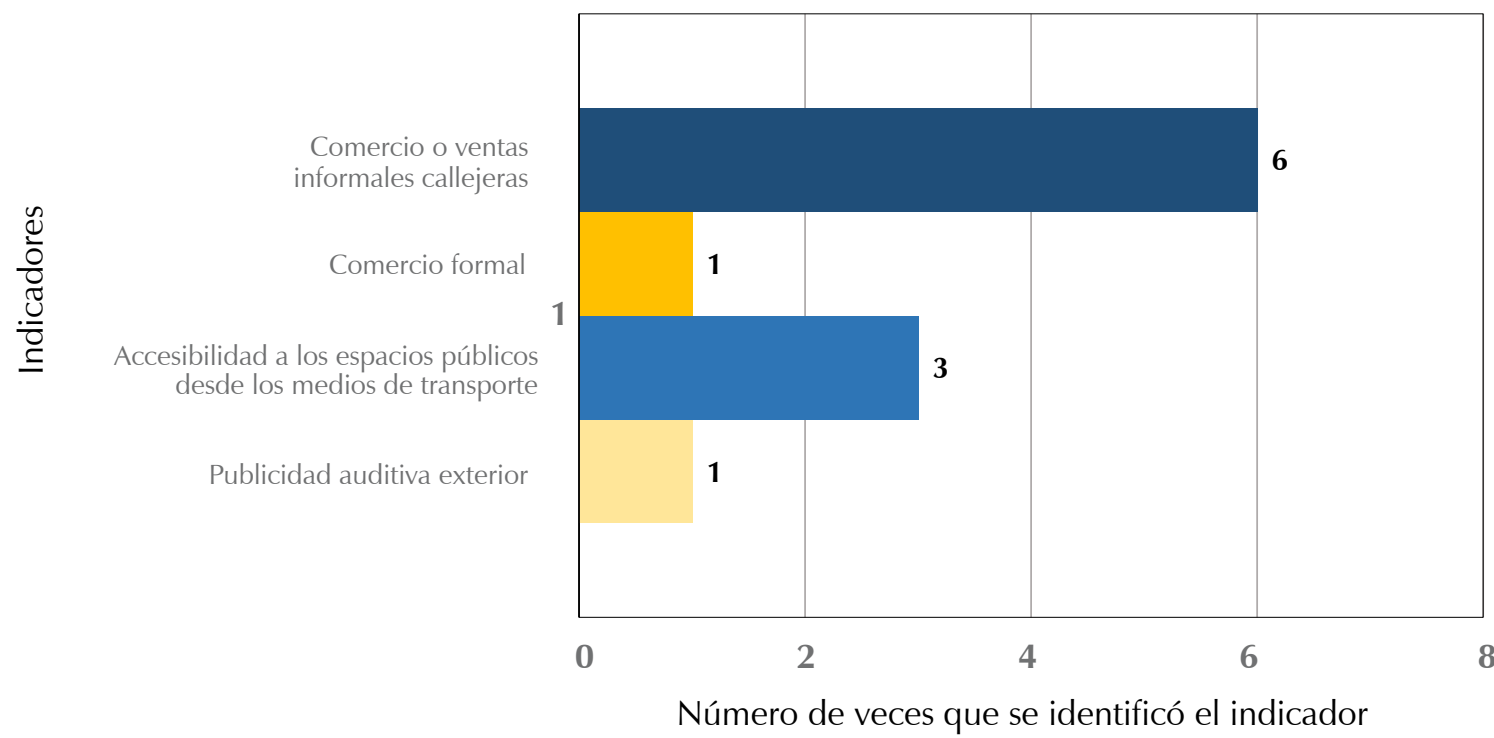

Figura 4. Indicadores identificados en la normativa de Rio de Janeiro

Fuente: elaboración propia.

Indicadores identificados en Belo Horizonte, Brasil

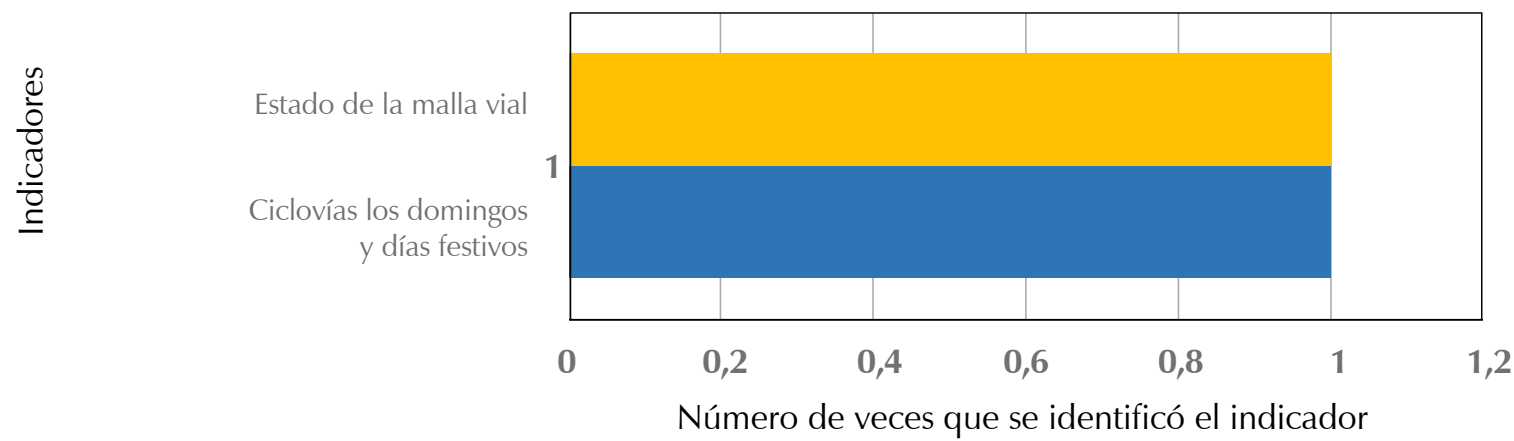

Figura 5. Indicadores identificados en normativa de Belo Horizonte

Fuente: elaboración propia.

Indicadores identificados de Ciudad de México

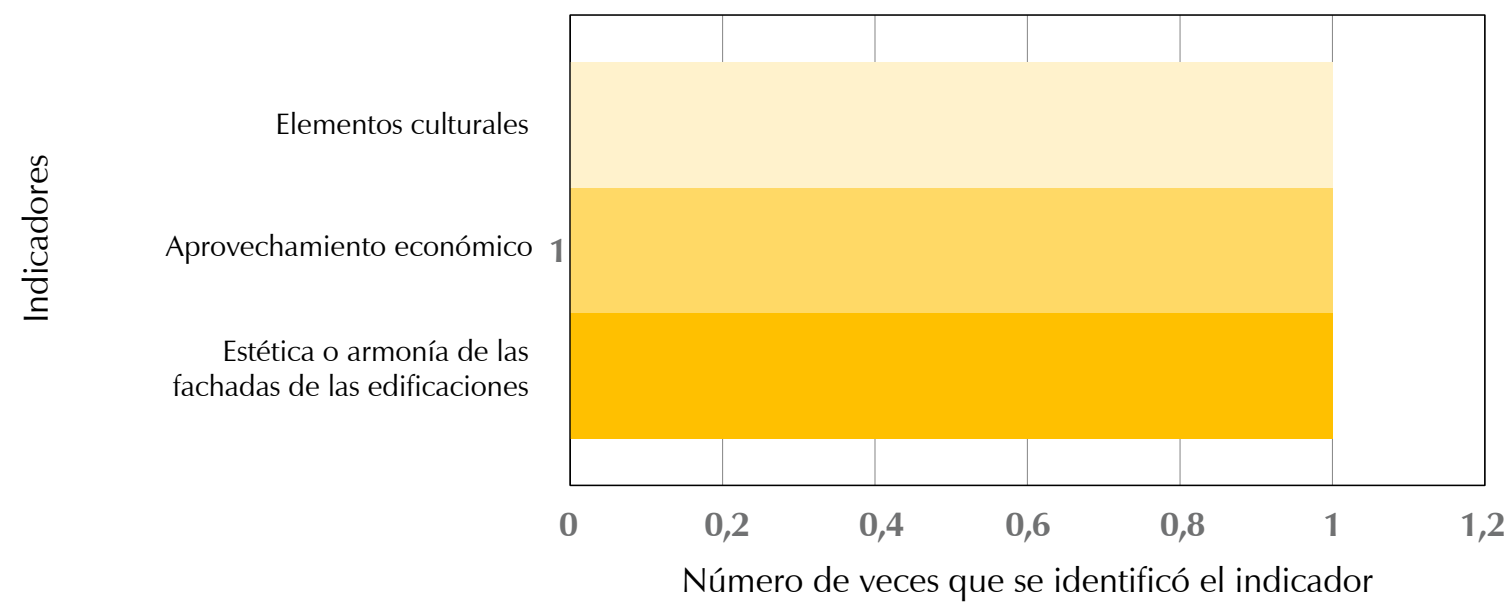

Figura 6. Indicadores identificados en la normativa de Ciudad de México

Fuente: elaboración propia. 
Indicadores identificados en Loja, Ecuador

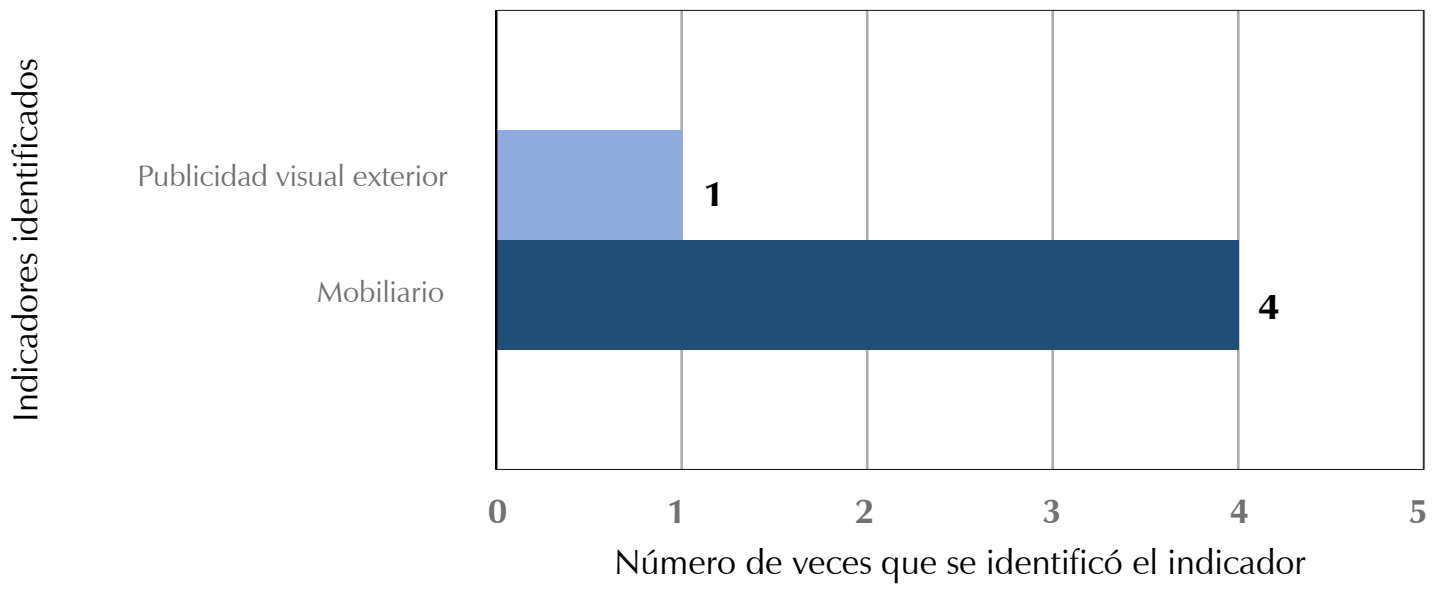

(2) Figura 7. Indicadores identificados en la normativa de la ciudad de Loja

Fuente: elaboración propia.

Indicadores identificados en Lima, Perú

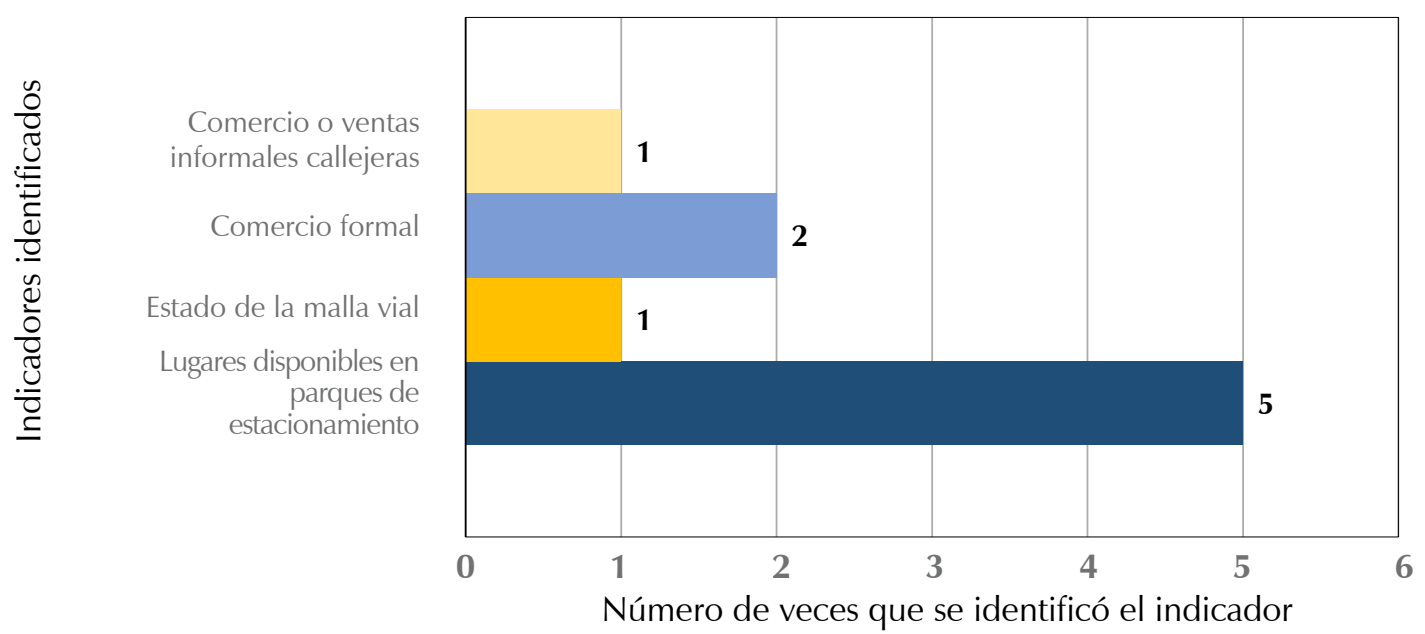

Figura 8. Indicadores identificados en la normativa de Lima Fuente: elaboración propia.
En Montevideo, Uruguay, se enuncian políticas públicas sobre la equidad en el espacio público general de las redes viales, circulaciones peatonales, ribera de los cursos de agua, zonas libres y de recreo. Es una ciudad que se centra en el derecho de todas las personas a acceder en condiciones no discriminatorias a equipamientos y servicios de uso público, declara el espacio público de interés general, resalta "la importancia de la preservación de los espacios públicos como lugar de convivencia, civismo, disfrute, de todas las personas que puedan desarrollar en libertad sus actividades preservando su libre circulación, ocio, encuentro y recreo, con respecto a la dignidad y a los derechos de los individuos". Penaliza la invasión del espacio público. Los tres indicadores relacionados con los temas que maneja en las políticas de espacio público son: que sea para todos, equitativo para todos los géneros, y que respete las reglas de convivencia.

En Lima, Perú, la norma se enfoca en las disposiciones de los espacios y las zonas de establecimiento vehicular temporal. Disposiciones aplicables a la tasa de estacionamiento en playas, uso de la vía pública y zonas rígidas para el comercio ambulatorio. Esta ciudad se centra en algunos de los problemas más graves, en cómo manejarlos, y define los lugares más apropiados para llevar a cabo las actividades comerciales o de servicio a fin de no tener que eliminarlas del espacio público ya que reconoce la importancia de la relación entre este y la actividad comercial. El mecanismo que emplea es el establecimiento de directrices para el manejo del problema.

En el caso de Medellín, Colombia, en su norma se encuentran desde definiciones hasta disposiciones sobre las áreas destinadas al tránsito público, vehicular o peatonal, o afectadas por este. Sobre los volantes publicitarios establece un procedimiento y un decreto para ejercer actividades comerciales temporales mediante proyectos de participación; los indicadores relacionados son publicidad visual exterior y comercio o ventas informales callejeras.

En Bogotá, Colombia, se maneja un Plan Maestro de espacio público que tiene por objeto concretar las políticas, estrategias, programas, proyectos y metas relacionados con el espacio público de esta ciudad, y establecer las normas generales que permitan alcanzar una regulación sistemática en cuanto a su generación, mantenimiento, recuperación y aprovechamiento económico, y apropiación social. 
Indicadores identificados en Bogotá, Colombia

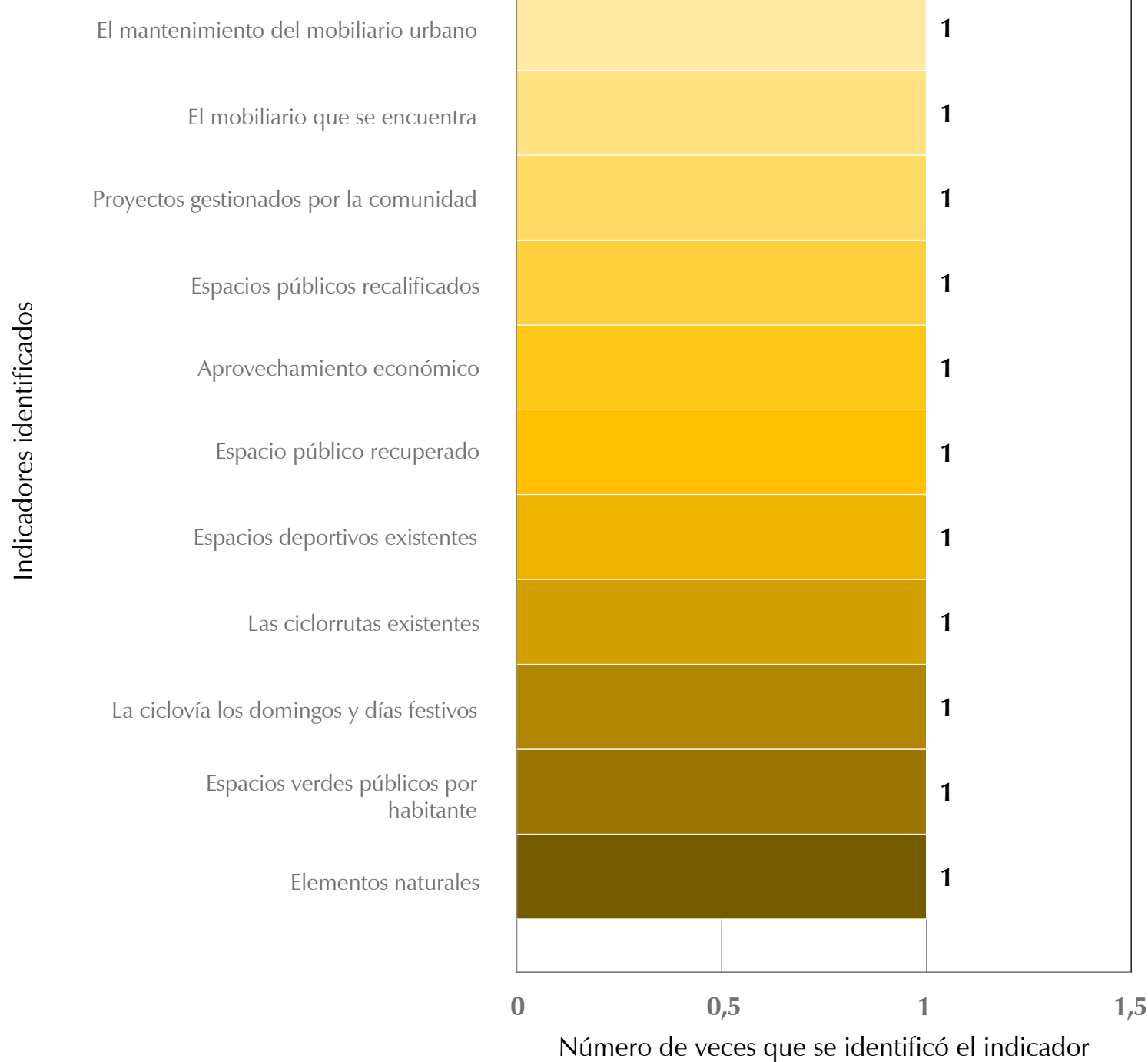

Figura 9. Indicadores identificados en la normativa de Bogotá D.C. Fuente: elaboración propia.
Reglamenta el aprovechamiento de arbolado aislado, los derechos y los deberes sociales, económicos y culturales en el espacio público. Otro gran aporte es el Plan de Ordenamiento Territorial (POT), por medio del cual especifica muchos de los tratamientos que se deben hacer en el espacio público. A nivel de indicadores se centra en las cesiones y en la consolidación de los nuevos espacios públicos, y la manera de adaptar los antiguos a la nueva reglamentación y necesidades de los ciudadanos. El manejo de una cartilla de espacio público centrada en dimensiones y materiales óptimos hace que la calidad y accesibilidad al espacio público sean tratadas de manera efectiva, cuyo mecanismo indiscutible es la regularización (Figura 9).

En Buenos Aires, Argentina, la norma señala que los espacios verdes o libres públicos de un núcleo urbano son dimensionados con base en la población potencial tope establecida por el Plan de Ordenamiento, adoptando un mínimo de diez metros cuadrados de área verde o libre por habitante, utilizando como mecanismo un indicador objetivo de metro cuadrado de área verde o libre por habitante. En la norma clasificada no se observa ninguna otra medida relacionada con indicadores, pero maneja datos de espacio público efectivo por habitante (Figura 10).

Del total de indicadores propuestos (92), se pudieron relacionar un total de 32 indicadores con los temas tratados en las políticas públicas revisadas, lo que corresponde al $35 \%$; vale la pena aclarar que estas son políticas disponibles en la web, y que en muchos casos se verá que en reglamentación de menor escala son tenidos en cuenta en mayor proporción; sin embargo, esa sería una investigación que requiere más profundización para realizarse a futuro. Tal como se aprecia en la Figura 10, el comercio o las ventas informales callejeras son el tema relacionado con un indicador más evidente en la política pública revisada, seguida del comercio formal, de los lugares para estacionar y la publicidad visual exterior, todos temas relacionados con actividades económicas con requerimientos de regulación para su manejo.

En cuanto a indicadores objetivos se puede apreciar que son pocos los que son nombrados en la norma latinoamericana de espacio público, solo algunas ciudades los tienen incluidos con algún tipo de medida específica, la mayoría solo se relacionan en cuanto al tema que se menciona de manera descriptiva e informativa, 
Total de indicadores identificados en la normativa de espacio público para 14 ciudades de estudio

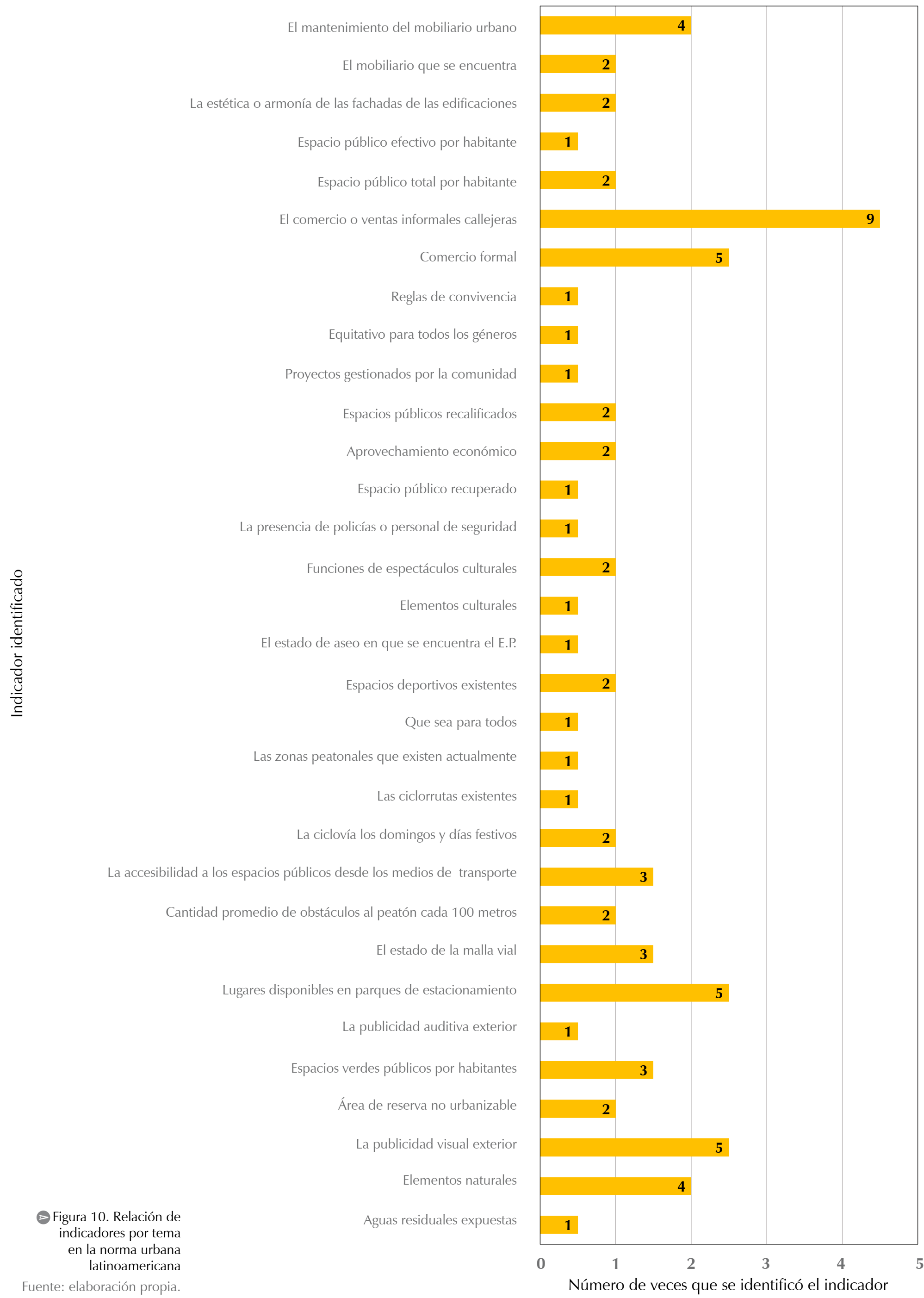


Espacio público efectivo por habitante

Espacio público total por habitante

El comercio o ventas informales callejeras

\author{
Comercio formal \\ Espacios públicos recalificados \\ Aprovechamiento económico \\ Espacio público recuperado \\ Espacios deportivos existentes \\ Las ciclorrutas existentes \\ Cantidad promedio de obstáculos al \\ peatón cada 100 metros \\ Lugares disponibles en parques de \\ estacionamiento \\ Espacios verdes públicos por \\ habitantes \\ Área de reserva no urbanizable
}

Aguas residuales expuestas

(a)

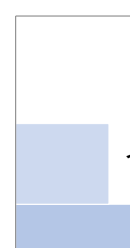

1

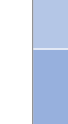

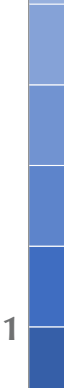

\title{
1
}

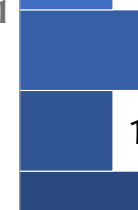

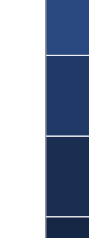

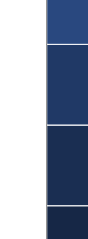

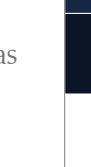

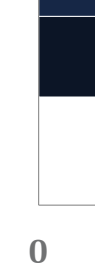

$\mathbf{0}$
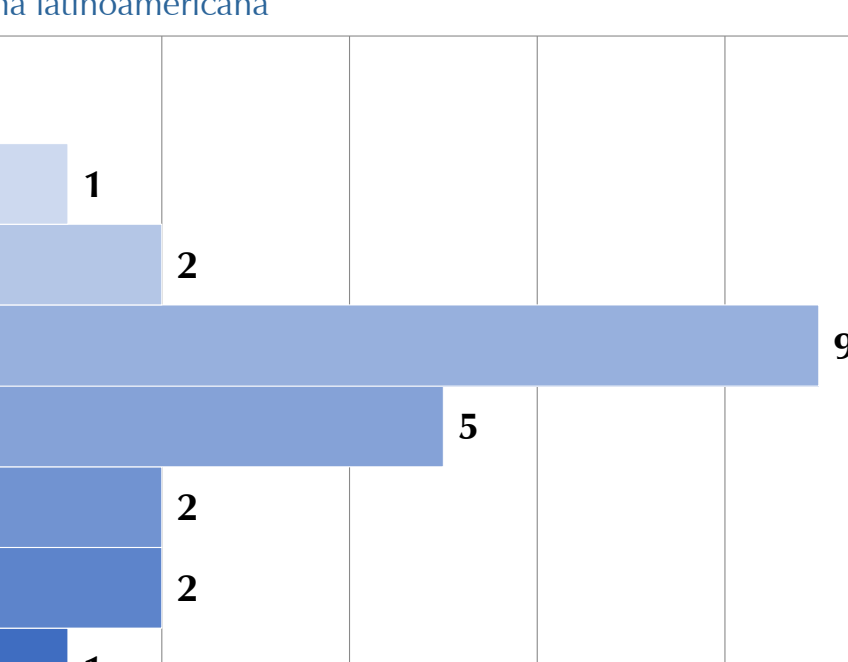

1
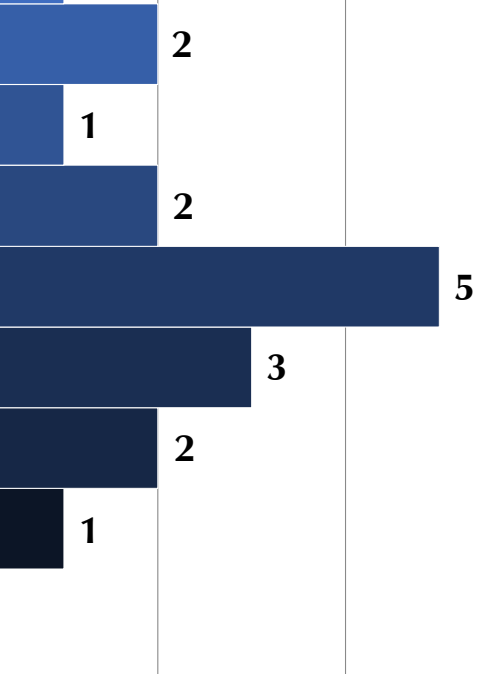

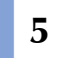

2

2

2

5

\section{2}

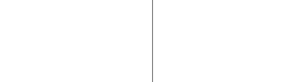

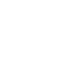

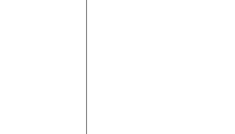

Número de veces que se identificó el indicador lo que permite identificar una oportunidad de estructurar la norma de una forma más concreta, y proponer el uso de indicadores como complemento a la formulación y regulación de la normativa ligada al espacio público de estas ciudades latinoamericanas. Se identificaron 14 indicadores relacionados con los temas tratados en las políticas, lo que corresponde a un $16 \%$ del total de indicadores propuestos y a un $16 \%$ del total de la batería de indicadores.

En general, se puede evidenciar que los indicadores subjetivos son escasos en las normas de las ciudades de estudio. Se observa el interés por caracterizar los elementos naturales y culturales, partiendo de la identificación y definición, pero no llegan a plantearse directrices articuladas al manejo de indicadores como referencia o punto comparativo (Figura 12).

Se puede apreciar que algunas ciudades presentan un manejo muy limitado de los temas sobre espacio público, otras ni siquiera los tienen en cuenta, y algunas se limitan a identificar los problemas y plantear una regulación a futuro. En algunas ciudades, en las que se abordan temas relacionados con los indicadores propuestos, estos se centran en el manejo o la solución temporal del problema presentado en el espacio público, pero no evidencian propuestas que a futuro promuevan un cambio determinante en las áreas que influyen en la habitabilidad de dicho espacio. En algunos casos es claro el hecho de que una problemática que presenta relación con varios campos tiene más opciones de ser priorizada e integrada a las políticas públicas que una que se centra en un solo tema componente del espacio público; entre más efectos tiene sobre los ciudadanos un tema más factible es su regulación. En el punto donde las ciudades pasaron del reconocimiento del espacio público y sus problemáticas a las propuestas específicas y están planeando a futuro, sería de gran aporte la implementación y el manejo de indicadores de habitabilidad del espacio público dentro de la normativa relacionada con estos, tratando de manera concreta y específica el tema que buscan fortalecer dentro de las políticas públicas, así el aporte sería significativo para los temas en los que se requiera profundizar y evolucionar en el futuro.

Alguna normativa de la revisada trata de ir más allá de la identificación y reglamentación del problema, y presenta un avance en cuanto al manejo que se plantea dar a los espacios públicos a futuro, tal es el caso de Bogotá, que incluye la renovación y el tratamiento de estos espacios en un plan maestro, y el manejo de una cartilla de espacio público que pretende estandarizar 
Indicadores objetivos identificados en la norma latinoamericana

El mantenimiento del mobiliario urbano

El mobiliario que se encuentra

La estética o armonía de las fachadas de las edificaciones

Reglas de convivencia

Equitativo para todos los géneros

Proyectos gestionados por la comunidad

La presencia de policías o personal de seguridad

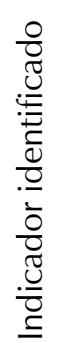

Funciones de espectáculos culturales

Elementos culturales

El estado de aseo en que se encuentra el E.P.

Para todos

Las zonas peatonales que existen actualmente

La ciclovía los domingos y días festivos La accesibilidad a los espacios públicos desde los medios de transporte

El estado de la malla vial

La publicidad auditiva exterior

La publicidad visual exterior

Elementos naturales

(A) Figura 12. Indicadores subjetivos identificados en los temas de norma urbana latinoamericana

Fuente: elaboración propia.

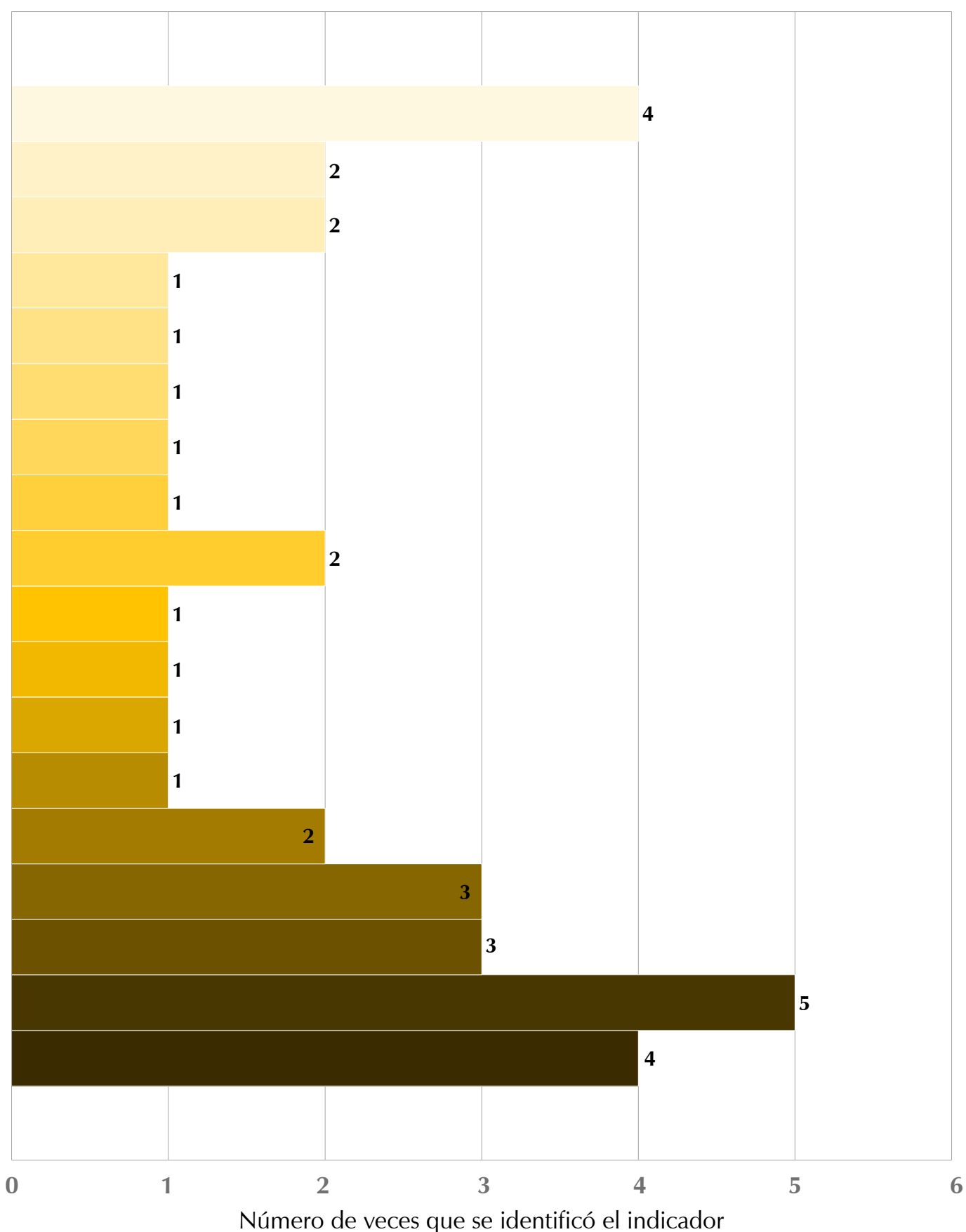

y caracterizar los elementos que lo complementan, como el caso del mobiliario urbano; así mismo, sugiere dimensiones óptimas y propone materiales para usar en andenes, escaleras, parques, plazoletas y alamedas, lo cual está relacionado con indicadores como estética, calidad de mobiliario, movilidad y elementos naturales, con manuales especializados para el tema. Bogotá tiene una serie de políticas amplias sobre el manejo del espacio público que la hacen una ciudad sobresaliente en comparación con otras urbes colombianas, eso se da porque la implementación de políticas va más allá de la descripción y el reconocimiento del espacio público direccionado al manejo de los problemas generales. Bogotá no se centra únicamente en solucionar sus problemas más graves, también le da importancia al manejo de nuevas directrices que a largo plazo promuevan políticas de avanzada para los problemas futuros de sus espacios públicos.
La revisión se realizó sobre la normativa de espacio público disponible en la red, que en la mayoría de los casos representa los marcos legales para otras de menor escala y jerarquía; no obstante que en esta norma general ya se identifica el interés de intervención sobre temas específicos relacionados con las problemáticas principales de la ciudad, es a nivel de norma complementaria donde se registra una profundización sobre temas que tienen en cuenta más ampliamente el manejo de indicadores de espacio público, pero el problema de este tipo de normativa complementaria es que aunque depende de la norma general, está ligada a los planes de desarrollo de los mandatos y a las metas de las entidades públicas a corto plazo, y en pocas ocasiones a planes generales de largo plazo, lo que no promueve su continuidad ya que está sujeta a los cambios e intervenciones que los mandatarios de turno quieran incluir como premisas de sus administraciones. 


\section{Conclusiones y recomendaciones}

A nivel general se puede concluir que la estructura de la normativa de espacio público en ciudades latinoamericanas sigue un orden en el planteamiento de sus políticas, que van del reconocimiento de conceptos relacionados con el espacio público hasta la propuesta de directrices específicas sobre el mismo y, en último lugar, con pocos casos, planteamientos de sostenibilidad y conservación a futuro. La revisión documental Ilevada a cabo sobre los indicadores del espacio público plantea la necesidad de desarrollar propuestas basadas en el cumplimiento de estándares de habitabilidad de dicho espacio. Sin embargo, la implementación de propuestas dirigidas a promover la habitabilidad del espacio público por medio de la política pública de las ciudades latinoamericanas no garantiza una eficiente implementación de la misma mientras las comunidades no sean integradas desde el punto de vista de resolver sus anhelos y necesidades con respecto a los espacios públicos de sus ciudades.

Por último, en la revisión de normativa urbana en ciudades latinoamericanas se evidencia la importancia de implementar la valoración del espacio público como una medida que apoye la toma de decisiones desde las políticas públicas dirigidas al mejoramiento de la calidad de vida urbana. En consecuencia, se hace necesario incorporar propuestas que permitan relacionar las evaluaciones de calidad de vida de sus habitantes con la valoración de la habitabilidad de sus espacios públicos, ya que estos se encuentran estrechamente relacionados, y el trabajo mancomunado permitiría aunar fuerzas y racionalizar recursos entre instituciones desde el direccionamiento de políticas generales. Con este fin, se recomienda como instrumento complementario a la normativa urbana existente en las ciudades latinoamericanas, la implementación de la batería de indicadores de habitabilidad de espacio público dentro de la estructura propuesta, con la incorporación de los indicadores de valoración de habitabilidad a la norma urbana de espacio público orientados a mejorar la calidad de vida en las ciudades.

Después de identificar los indicadores cuantitativos y cualitativos relacionados con calidad de vida urbana, este estudio se propuso relacionar cuáles de ellos podrían estar dirigidos a valorar la habitabilidad del espacio público desde el punto de vista objetivo y subjetivo de la valoración.

Al revisar el manejo y la implementación de los indicadores propuestos en la batería de valoración de habitabilidad del espacio público en la política pública de las ciudades latinoamericanas seleccionadas — profundizando en la ciudad de Bogotá como caso de estudio- , se pudo evidenciar que la norma de espacio público es aún muy general, descriptiva y conceptual. Se apoya poco en indicadores, y los que escasamente maneja no permiten tener un panorama real en temas de habitabilidad del espacio público. Es por ello que se puede confirmar que la implementación de una batería de indicadores contribuiría de forma positiva a complementar la información requerida para la toma de decisiones y la propuesta de directrices sobre los espacios públicos urbanos, para incluir en las políticas públicas las acciones que sean necesarias con respecto a la habitabilidad de los espacios públicos en ciudades latinoamericanas.

En la revisión de la norma urbana de espacio público en las ciudades latinoamericanas seleccionadas, se determinaron los temas que son tenidos en cuenta con el fin de relacionarlos con aquellos tratados por medio de los indicadores propuestos. De este modo se identificaron 32 temas relacionados con los indicadores, hacia los cuales se direccionaba el manejo de la norma, de lo cual se pudo evidenciar, a nivel general, que dichos temas corresponden a la problemática dominante de las ciudades, lo cual direcciona la norma para solucionar temas específicos, más allá de proponer estrategias de mejoramiento sostenible en el tiempo. Por otra parte, el análisis de la normativa demuestra un claro enfoque de la reglamentación hacia el manejo de los espacios públicos existentes, pero no plantea directrices o propuestas hacia el planeamiento de los nuevos espacios, solo se evidencian unos pocos casos en los que indicadores objetivos son exigidos como componente de propuestas futuras. La normativa revisada tampoco evidencia interés por plantear propuestas que incluyan el manejo de indicadores subjetivos en proyectos en etapa de planificación, lo cual podría prever un desacierto a futuro con respecto a las decisiones tomadas, al no tener en cuenta los deseos y requerimientos de los usuarios.

La batería de indicadores de habitabilidad de los espacios públicos pretende apoyar procesos desde el diseño de nuevos espacios hasta la renovación de los antiguos, como parte de una estrategia que promueva la tendencia a recuperar y recalificar los espacios públicos de las ciudades latinoamericanas; para el caso de los nuevos, la batería promovería la apropiación de los mismos ya que estos serían concebidos según los deseos y las necesidades de los usuarios, con unos parámetros mínimos de habitabilidad desde el punto de vista objetivo de las políticas públicas, dirigidos a tendencias y requerimientos de funcionalidad y sostenibilidad.

Finalmente, el estudio propone una batería de indicadores organizados a partir de una estructura que contribuye a orientar políticas y acciones de planeación y de gestión del espacio público en las ciudades latinoamericanas. El instrumento propuesto está conformado por 9 categorías y 92 indicadores dirigidos a valorar la habitabilidad del espacio público, los cuales podrían estandarizarse de tal manera que posibiliten, no solo hacerse monitorías a políticas públicas de desarrollo y gestión 
urbana, sino hacer comparación entre ciudades. Para la aplicación del instrumento se propone que desde las entidades públicas se promueva el uso y el acceso a la información que sobre los espacios públicos de las ciudades se pueda requerir, ya que los indicadores objetivos demandan en la mayoría de los casos instrumentos o cálculos precisos, que deben partir de información verificable y actualizada. En el caso de los indicadores subjetivos, estos pueden ser manejados desde encuestas a la comunidad beneficiaria de los espacios. Este tipo de instrumento agregaría gran valor al desarrollo de los diseños o las intervenciones que se planeen con las comunidades, ya que daría parámetros claros de las necesidades y los requerimientos de las comunidades. Para el caso de los indicadores subjetivos se plantea adoptar el instrumento propuesto por Páramo y Burbano (2013) en la valoración de espacios públicos urbanos, y en el caso de los indicadores objetivos se recomienda que las mediciones estén relacionadas con unos datos de partida que desde las entidades se manejen como mínimos, óptimos o esperados, y permitan, desde un grado comparativo, establecer la valoración de dicho indicador.

\section{Referencias}

Alfonso P. W. (2010). El concepto de hábitat en medios urbanos: una transición del pensamiento urbano del siglo XX. Traza 1 (2). Recuperado de http://revistas.lasalle.edu. co/index.php/tr/article/view/406

Banco Mundial (2007). Informe anual 2007. Washington: Banco Internacional de Reconstrucción y Fomento. Recuperado de http://siteresources.worldbank.org/EXTANNREP2K7/Resources/Spanish.pdf

Bogotá cómo vamos (2014). Informe de calidad de vida 2014. Bogotá: Cámara de Comercio. Recuperado de: http://www. bogotacomovamos.org/documentos/informe-de-calidad-de-vida-2014-3/

Bogotá cómo vamos (2015). Informe de calidad de vida 2014. Bogotá: Cámara de Comercio.

Carr, S., Francis. M., Riviin. L. y Stone, A. (1992) Public Space. New York: Cambridge University Press.

DANE (2014). Encuesta Nacional de Calidad de Vida 2014. Recuperado de https://www. dane.gov.co/index.php/estadisticas-portema/salud/calidad-de-vida-ecv/encuestanacional-de-calidad-de-vida-2014

Hábitat (2008). Definición de. Recuperado de http://definicion.de/habitat/

Decreto 215 de 2005 [Alcaldía Mayor de Bogotá, D.C.]. Plan Maestro de Espacio Público para Bogotá Distrito Capital. 7 de julio de 2005.

Decreto 319 de 2006 [Alcaldía Mayor de Bogotá, D.C.]. Plan Maestro de Movilidad para Bogotá Distrito Capital. 15 de agosto de 2006.

Departamento Administrativo de Estadística (DANE) (2015). Sistema Estadístico Nacional (SEN). Recuperado de https://www. dane.gov.co/index.php/sistema-estadisticonacional-sen/que-es-el-sistema-estadisticonacional

Departamento Administrativo de la Defensoría del Espacio Público (DADEP) (s. f.). Indicadores de espacio público para Bogotá. Recuperado de http://www. dadep.gov.co/index.php/component/ phocadownload/category/15-dimension-urbana?download $=5$ : indicadores-deespacio-publico-para-bogota

Departamento Administrativo de la Defensoría del Espacio Público (DADEP) (2013). Sentido urbano. Una mirada el espacio público de Bogotá. Estándares y metodología de medición de indicadores de espacio público. Recuperado de http:// investigacion.dadep.gov.co/publicaciones/ sentidourbano/1.pdf

Franck, K. A. y Stevens, Q. (2007). Loose Space. New York: Routledge.

Gehl, J. y Svarre, B. (2013). How to Study Public life. Washington: IslandPress. doi: 10.5822/9781-61091-525-0.

Gehl, J. (1997). Life Between Buildings. Using Public Space. New York: Van Nostrand Reinhold.

Gehl, J. (2014). Ciudades para la gente. Buenos Aires: Ediciones Infinito.

Wessels, G., Pardo, C. F. y Bocarejo, J. P. (2012). Bogotá 21. Hacia una metrópoli de clase mundial orientada al transporte público. Bogotá: Fundación Despacio. Recuperado de http://despacio.org/wpcontent/uploads/2012/10/Bogota-21-espanol.pdf

Hoornweg, D., Ruiz, F., Freire, M., Palugyai, N., Villaveces, M. y Wills, E. (2007). Citylndicators: Now to Nanjing. Wolrd Bank PolicyWorkingPaper for Third World Urban Forum, Vancouver. Recuperado de http:// documentos.bancomundial.org/curated/ es/707781468263936449/pdf/wps4114.pdf

Jardín Botánico José Celestino Mutis (JBJCM (2013). Sistema de información para la gestión del arbolado urbano Bogotá D.C. SIGAU. Recuperado de http://www.jbb.gov. co/index.php/sigau

Leva, G. (2005). Indicadores de calidad de vida urbana. Teoría y metodología. Buenos Aires: Universidad Nacional de Quilmes y Hábitat Metrópolis.

Morril, C., Snow, D. A. y White, C. (2005). Together alone: Personal relationships in public places. Berkeley: University of California Press.

Observatorio Ambiental de Bogotá D.C. (s. f.). Indicadores ambientales. Bogotá: Secretaría Distrital de Ambiente. Recuperado de http://oab.ambientebogota.gov.co/es/ temas? $v=4 \& p=21$

Páramo (2010). El espacio público y la calidad de vida urbana. En Páramo, P. y García, M E. (coords.). La dimensión social del espacio público. Aportes para la calidad de vida urbana. Bogotá: Universidad Pedagógica Nacional-Universidad Santo Tomás.

Páramo, P. y Burbano, A. (2013). Valoración de las condiciones que hacen habitable el espacio público en Colombia. Revista Territorios, 28, 187-206. Recuperado de http:// revistas.urosario.edu.co/index.php/territorios/article/view/2557
Páramo, P. y Burbano, A. M. (2014a). La Ciudad Habitable: espacio público y sociedad. Bogotá: Universidad Piloto de Colombia.

Páramo, P., \& Burbano Arroyo, A. (2014b). Los usos y la apropiación del espacio público para el fortalecimiento de la democracia. Revista de Arquitectura, 16(1), 6-15. doi:http://dx.doi.org/10.14718/RevArq. 2014.16.2

Páramo, P. y Burbano, A. M. (2015). Estudio comparado de la normatividad sobre espacio público en América Latina. En Estudio comparado de espacio público en ciudades latinoamericanas. Bogotá: Universidad Piloto de Colombia.

Plan Maestro de Ciclorrutas para Bogotá Distrito Capital (1998). Contrato de Consultoría No. 0.27 de 1998, celebrado con el Instituto de Desarrollo Urbano (IDU) para la realización de los estudios para la formulación del Plan Maestro de Ciclo-rutas (PMC) para la ciudad de Santa Fe de Bogotá. Bogotá: Alcaldía Mayor de Bogotá. Recuperado de https://www.idu.gov.co/atencion-al-ciudadano/infraestructura-cicloinclusiva/planmaestro-de-ciclorutas

Red colombiana de Ciudades Cómo Vamos (2014). Indicadores de calidad de vida. Recuperado de: http://redcomovamos.org/bilioteca/

Saldarriaga, A. (1981). Habitabilidad. Bogotá: Escala.

Secretaría Distrital de Planeación (SDP) (2012). Documento Sistema Integral de Información para la Planeación del Distrito (SIIPD), de los años 2008-2012. Recuperado de http:// www.sdp.gov.co/portal/page/portal/PortalSDP/InformacionTomaDecisiones/documentoconceptualversion.pdf

Torres, A. (2014). Territorios urbanos como espacios comunitarios. En Burbano, A. y Páramo, P. (comps.). La ciudad habitable: espacio público y sociedad. Bogotá: Universidad Piloto de Colombia.

Uribe, J. (2011). La investigación documental y el estado del arte como estrategias de investigación en ciencias sociales. En Páramo, P (coord.). La Investigación en Ciencias Sociales: estrategias de investigación. Bogotá: Universidad Piloto de Colombia. 
La postulación de un artículo a la Revista de Arquitectura indica que- el o los autores certifican que conocen y aceptan la política editorial, para lo cual firmarán en original y remitirán el formato RevArq FP00 Carta de originalidad.

La Revista de Arquitectura maneja una política de Autoarchivo VERDE, según las directrices de SHERPA/RoMEO, por lo cual el autor puede:

- Pre-print del autor: Archivar la versión pre-print (la versión previa a la revisión por pares)

- Post-print del autor: Archivar la versión post-print (la versión final posterior a la revisión por pares

- Versión de editor/PDF: Archivar la versión del editor - PDF/HTML/XLM en la maqueta de la Revista de Arquitectura.

El Autoarchivo se debe hacer respetando la licencia de acceso abierto, la integridad y la imagen de la Revista de Arquitectura, también se recomienda incluir la referencia, el vínculo electrónico y el DOI.

El autor o los autores son los titulares del Copyright (c) del texto publicado y la Editorial de la Revista de Arquitectura solicita la firma de una autorización de reproducción del artículo (RevArq FP03 Autorización reproducción), la cual se acoge a la licencia CC, donde se expresa el derecho de primera publicación de la obra.

La Revista de Arquitectura se guía por las normas internacionales sobre propiedad intelectual y derechos de autor, y de manera particular el artículo 58 de la Constitución Política de Colombia, la Ley 23 de 1982 y el Acuerdo 172 del 30 de septiembre de 2010 (Reglamento de propiedad intelectual de la Universidad Católica de Colombia).

Para efectos de autoría y coautoría de artículos se diferencian dos tipos: "obra en colaboración" y "obra colectiva". La primera es aquella cuya autoría corresponde a todos los participantes al ser fruto de su trabajo conjunto. En este caso, quien actúa como responsable y persona de contacto debe asegurar que quienes firman como autores han revisado y aprobado la versión final, y dan consentimiento para su divulgación. La obra colectiva es aquella en la que, aunque participan diversos colaboradores, hay un autor que toma la iniciativa, la coordinación y realización de dicha obra. En estos casos, la autoría corresponderá a dicha persona (salvo pacto en contrario) y será suficiente únicamente con su autorización de divulgación.

El número de autores por artículo debe estar justificado por el tema, la complejidad y la extensión, y no deberá ser superior a la media de la disciplina, por lo cual se recomienda que no sea mayor de cinco. El orden en que se enuncien corresponderá a los aportes de cada uno a la construcción del texto, se debe evitar la autoría ficticia o regalada. Si se incluyen más personas que trabajaron en la investigación se sugiere que sea en calidad de colaboradores o como parte de los agradecimientos. La Revista de Arquitectura respetará el número y el orden en que figuren en el original remitido. Si los autores consideran necesario, al final del artículo pueden incluir una breve descripción de los aportes individuales de cada uno de firmantes.

La comunicación se establece con uno de los autores, quien a su vez será el responsable de informar a los demás autores de las notificaciones emitidas por la Revista de Arquitectura.

En virtud de mantener el equilibro de las secciones y las mismas oportunidades para todos los participantes, un mismo autor puede postular dos o más artículos de manera simultánea; si la decisión editorial es favorable y los artículos son aceptados, su publicación se realizará en números diferentes.

\section{A Acceso abierto}

La Revista de Arquitectura, en su misión de divulgar la investigación y apoyar el conocimiento y la discusión en los campos de interés, proporciona acceso abierto, inmediato e irrestricto a su contenido de manera gratuita mediante la distribución de ejemplares impresos y digitales. Los interesados pueden leer, descargar, guardar, copiar y distribuir, imprimir, usar, buscar o referenciar e texto completo o parcial de los artículos o la totalidad de la Revista de Arquitectura.

\section{(c) (1) (3)}

Esta revista se acoge a la licencia Creative Commons (CC BYNC de Atribución - No comercial 4.0 Internacional): "Esta licencia permite a otros entremezclar, ajustar y construir a partir de su obra con fines no comerciales, y aunque en sus nuevas creaciones deban reconocerle su autoría y no puedan ser utilizadas de manera comercial, no tienen que estar bajo una licencia con los mismos términos".

La Revista de Arquitectura es divulgada en centros y grupos de investigación, en bibliotecas y universidades, y en las principales facultades de Arquitectura, mediante acceso abierto a la versión digital y suscripción anual al ejemplar impreso o por medio de canje, este último se formaliza mediante el formato RevArq FP20 Canjes.

Para aumentar su visibilidad y el impacto de los artículos, se envían a bases de datos y sistemas de indexación y resumen (SIR) y, asimismo, pueden ser consultados y descargados en la página web de la revista.

La Revista de Arquitectura no maneja cobros, tarifas o tasas de publicación de artículo (Article Processing Charge-APC), o por el sometimiento de textos a la publicación.

\section{(1)Ética y buenas prácticas}

La Revista de Arquitectura se compromete a cumplir y respetar las normas éticas en todas las etapas del proceso de publicación. Los autores de los artículos publicados darán cumplimiento a los principios éticos contenidos en las diferentes declaraciones y legislaciones sobre propiedad intelectual y derechos de autor específicos del país donde se realizó la investigación. En consecuencia, los autores de los artículos postulados y aceptados para publicar, que presentan resultados de investigación, deben firmar la declaración de originalidad (formato RevArq FP00 Carta de originalidad).

La Revista de Arquitectura reconoce y adopta los principios de transparencia y buenas prácticas descritos por COPE, "Principles of Transparency and Best Practice in Scholarly Publishing" (2015).

El equipo editorial tiene la obligación de guardar la confidencialidad acerca de los artículos recibidos, y abstenerse de usar en sus propias investigaciones datos, argumentos o interpretaciones hasta tanto el artículo no sea publicado. También debe ser imparcial y gestionar los artículos de manera adecuada y en los plazos establecidos. La selección de revisores se hará con objetividad y estos deberán responder a la temática del artículo.

El editor, los autores y los revisores deben seguir las normas éticas internacionales definidas por el Committee on Publication Ethics (COPE), con el fin de evitar casos de:

- Fabricación, falsificación u omisión de datos.

- Plagio y autoplagio.

- Publicación redundante, duplicada o fragmentada.

- Omisión de referencias a las fuentes consultadas.

- Utilización de contenidos sin permiso o sin justificación.

- Apropiación individual de autoría colectiva.

- Cambios de autoría.

- Conflicto de interés (CDI) no revelado o declarado.

- Otras que pudieran surgir en el proceso de investigación y publicación. La fabricación de resultados se genera al mostrar datos inventados por los autores; la falsificación resulta cuando los datos son manipulados y cambiados a capricho de los autores; la omisión se origina cuando los autores ocultan deliberadamente un hecho o dato. El plagio se da cuando un autor presenta como ideas propias datos creados por otros. Los casos de plagio son los siguientes: copia directa de un texto sin entrecomillar o citar la fuente, modificación de algunas palabras del texto, paráfrasis y falta de agradecimientos; el autoplagio se da cuando el mismo autor reutiliza material propio que ya fue publicado, pero sin indicar la referencia al trabajo anterior. La revista se apoya en herramientas digitales que detectan cualquiera de estos casos en los artículos postulados, y es labor de los editores y revisores velar por la originalidad y fidelidad en la citación. La publicación redundante o duplicada se refiere a la copia total, parcial o alterada de un trabajo ya publicado por el mismo autor

En caso de sospechar de alguna mala conducta se recomienda seguir los diagramas de flujo elaborados por COPE (2008), con el fin de determinar las acciones correspondientes.

La Revista de Arquitectura se reserva el derecho de retractación de publicación de aquellos artículos que, posterior a su publicación, se demuestre que presentan errores de buena fe, o cometieron fraudes o malas prácticas científicas. Esta decisión se apoyará en "Retraction Guidelines" (COPE, 2009). Si el error es menor, este se podrá rectificar mediante una nota editorial de corrección o una fe de erratas. Los autores también tienen la posibilidad de solicitar la retractación de publicación cuando descubran que su trabajo presenta errores graves. En todos los casos se conservará la versión electrónica y se harán las advertencias de forma clara e inequívoca.

\section{(A) Privacidad y manejo de la información.} Habeas Data

Para dar cumplimiento a lo previsto en el artículo 10 del Decreto 1377 de 2013, reglamentario de la Ley 1581 de 2012, y según el Acuerdo 002 del 4 de septiembre de 2013 de la Universidad Católica de Colombia, "por el cual se aprueba el manual de políticas de tratamiento de datos personales":

La Universidad Católica de Colombia, considerada como responsable o encargada del tratamiento de datos personales, manifiesta que los datos personales de los autores, integrantes de los comités y pares revisores, se encuentran incluidos en nuestras bases de datos; por lo anterior, y en cumplimiento de las disposiciones legales vigentes, la Universidad solicitará siempre su autorización, para que en desarrollo de sus funciones propias como Institución de Educación Superior, en especial las relacionadas con la docencia, la extensión y la investigación, la Universidad Católica de Colombia pueda recolectar, recaudar, almacenar, usar, circular, suprimir, procesar, intercambiar, compilar, dar tratamiento, actualizar, transmitir o transferir a terceros países y disponer de los datos que le han suministrado y que han sido incorporados en las bases de datos de todo tipo que reposan en la Universidad.

La Universidad Católica de Colombia queda autorizada, de manera expresa e inequívoca, en los términos señalados por el Decreto 1377 de 2013, para mantener y manejar la información de nuestros colaboradores (autores, integrantes de los diferentes comités y pares revisores); así mismo, los colaboradores podrán ejercer sus derechos a conocer, actualizar, rectificar y suprimir sus datos personales, para lo cual se han dispuesto las siguientes cuentas de correo electrónico: 
La Revista de Arquitectura recibe artículos de manera permanente. Los artículos se procesan a medida que se postulan, dependiendo el flujo editorial de cada sección.

El idioma principal es el español, y como opcionales están definidos el inglés, el portugués y el francés; los textos pueden ser escritos y presentados en cualquiera de estos.

Los artículos postulados deben corresponder a las categorías universalmente aceptadas como producto de investigación, ser originales e inéditos y sus contenidos responder a criterios de precisión, claridad y brevedad.

Como punto de referencia se pueden tomar las tipologías y definiciones del Índice Bibliográfico Nacional, Publindex (2010) que se describen la continuación:

1. Artículo de revisión: documento resultado de una investigación terminada donde se analizan, sistematizan e integran los resultados de investigaciones publicadas o no publicadas, sobre un campo en ciencia o tecnología, con el fin de dar cuenta de los avances y las tendencias de desarrollo. Se caracteriza por presentar una cuidadosa revisión bibliográfica de por lo menos 50 referencias.
2. Artículo de investigación científica y tecnológica: documento que presenta, de manera detallada, los resultados originales de proyectos terminados de investigación. La estructura generalmente utilizada contiene cuatro apartes importantes: introducción, metodología, resultados y conclusiones.

3. Artículo de reflexión: documento que presenta resultados de investigación terminada desde una perspectiva analítica, interpretativa o crítica del autor, sobre un tema específico, recurriendo a fuentes originales.

En todos los casos se debe presentar la información suficiente para que cualquier investigador pueda reproducir la investigación y confirmar o refutar las interpretaciones defendidas.

También se pueden presentar otro tipo de documentos diferentes a los anteriormente descritos, como pueden ser: artículo corto, reporte de caso, revisión de tema, documento resultado de la revisión crítica de la literatura sobre un tema en particular, cartas al editor, traducción, documento de reflexión no derivado de investigación, reseña bibliográfica, así como proyectos de arquitectura o urbanismo, entre otros

\section{A Instrucciones para postular artículos}

Postular el artículo en la página web de la Revista de Arquitectura y adjuntar comunicación escrita dirigida al editor RevArq_FP00 Carta de originalidad (debidamente firmada por todos los autores en original); de igual manera, se debe diligenciar el formato de hoja de vida RevArq FP01 Hoja de Vida (una por cada autor).

En la comunicación escrita el autor expresa que conoce y acepta la política editorial de la Revista de Arquitectura, que el artículo no está postulado para publicación simultáneamente en otras revistas u órganos editoriales y que no existe conflicto de intereses (ver modelo RevArq FP06 CDI) y que, de ser aceptado, concederá permiso de primera publicación, no exclusiva a nombre de la Universidad Católica de Colombia como editora de la revista.

Los artículos deben tener en cuenta las siguientes recomendaciones:

- En la primera página del documento se debe incluir:

Título: no exceder 15 palabras.

Subtítulo: opcional, complementa el título o indica las principales subdivisiones del texto.

Nombre del autor o autores: nombres y apellidos completos o según modelo de citación adoptado por el autor para la normalización de los nombres del investigador. Como nota al pie (máximo 150 palabras): formación académica, experiencia profesional e investigativa, vinculación laboral, código ORCID, premios o reconocimientos, publicaciones representativas e información de contacto, correo electrónico.

Filiación institucional: debajo del nombre se debe declarar la institución en la cual se desarrolló el producto, de la cual recibió apoyo o aquella que respalda el trabajo investigativo.

Resumen: debe ser analítico, se redacta en un solo párrafo, da cuenta del tema, el objetivo, la metodología, los resultados y las conclusiones; no debe exceder las 150 palabras.

Palabras clave: cinco palabras o grupo de palabras, ordenadas alfabéticamente y que no se encuentren en el título o subtítulo; estas sirven para clasificar temáticamente al artículo. Se recomienda emplear principalmente palabras definidas en el tesauro de la Unesco (http:// databases.unesco.org/thessp/), en el tesauro de Arte \& Arquitectura (C (www.aatespanol.cl), o Vitruvio (http://vocabularyserver.com/vitruvio/)

También se recomienda incluir título, resumen y palabras clave en segundo idioma.

\section{- La segunda página y siguientes deben tener en cuenta:}

El cuerpo del artículo generalmente se divide en: Introducción, Metodología, Desarrollo, Resultados y Discusión de resultados; posteriormente se presentan las Conclusiones, y luego las Referencias bibliográficas y los Anexos (método IMRYD). Las tablas y figuras se deben incorporar en el texto.

Descripción del proyecto de investigación: en la introducción se debe describir el tipo de artículo y brevemente el marco investigativo del cual es resultado y diligenciar el formato (RevArq FP02 Info Proyectos de Investigación).

TEXTO: todas las páginas deben venir numeradas y con el título de artículo en la parte superior de la página. Márgenes de $3 \mathrm{~cm}$ por todos los lados, interlineado doble, fuente Arial o Times New Roman de 12 puntos, texto justificado (Ver plantilla para presentación de artículos). La extensión de los artículos debe ser de alrededor de 5.000 palabras ( \pm 20 páginas, incluyendo gráficos, tablas, referencias, etc.); como mínimo 3.500 y máximo 8.000 palabras. Se debe seguir el estilo vigente y recomendado en el Manual para Publicación de la American Psychological Association (APA). (Para mayor información véase http://www.apastyle.org/)
Citas y notas al pie: las notas aclaratorias o notas al pie no deben exceder cinco líneas o 40 palabras, de lo contrario estas deben ser incorporadas al texto general. Las citas pueden ser:

Corta: (con menos de 40 palabras) se incorporan al texto y pueden ser: textuales (se encierran entre dobles comillas), parafraseo o resumen (se escriben en palabras del autor dentro del texto).

Cita textual extensa: (mayor de 40 palabras) debe ser dispuesta en un renglón y un bloque independiente con sangrías y omitiendo las comillas, no olvidar en ningún caso la referencia del autor (Apellido, año, página).

Referencias: como modelo para la construcción de referencias se emplea el estilo recomendado en el Manual para Publicación de la American Psychological Association (APA) (http://www.apastyle.org/).

Siglas: en caso de emplear siglas en el texto, las figuras o las tablas, se debe proporcionar la equivalencia completa la primera vez que se empleen y encerrarlas entre paréntesis. En el caso de citar personajes reconocidos se deben colocar nombres o apellidos completos, nunca emplear abreviaturas.

Figuras y tablas: las figuras (gráficos, diagramas, ilustraciones, planos, mapas o fotografías) y las tablas deben ir numeradas y contener título o leyenda explicativa relacionada con el tema del artículo, que no exceda las 15 palabras (Figura 1. xxxxx, Tabla 1. xxxx, etc.) y la procedencia (fuente: autor o fuente, año, página). Estas se deben referenciar en el texto de forma directa o entre paréntesis; se recomienda hacerlo con referencias cruzadas.

También se deben entregar en medio digital, independiente del texto, en formatos editables o abiertos. La marcación de los archivos debe corresponder a la incluida en el texto. Según la extensión del artículo se deben incluir de 5 a 10 gráficos. Ver guía para la búsqueda de imágenes de dominio público o bajo licencias Creative Commons (CC).

El autor es el responsable de adquirir los derechos o las autorizaciones de reproducción a que haya lugar para imágenes o gráficos tomados de otras fuentes, así como de entrevistas o material generado por colaboradores diferentes a los autores; de igual manera, se debe garantizar la protección de datos e identidades para los casos que sea necesario.

FOTOGRAFíA: pueden ser entregadas en original para ser digitalizadas, de lo contrario se deben digitaliza r con una resolución igual o superior a 300 dpi para imágenes a color y 600 para escala de grises. Los formatos de las imágenes pueden ser TIFF, PSD o JPG, y deben cumplir con las características expresadas en el punto anterior (figuras).

Planimetría: se debe entregar la planimetría original en medio digital, en lo posible en formato CAD, y sus respectivos archivos de plumas o en PDF; de no ser posible, se deben hacer impresiones en tamaño carta con las referencias de los espacios mediante numeración y lista adjunta. Deben tener escala gráfica, escala numérica, norte, coordenadas y localización. En lo posible, no deben contener textos, achurados o tramas.

Para más detalles, consultar el documento RevArq Parámetros para Autores Descripción en el portal web de la Revista de Arquitectura

\section{Beneficios}

Como reconocimiento a los autores, se les hará envío postal de dos ejemplares de la edición impresa sin ningún costo y entregada en la dirección consignada en el formato de hoja de vida (RevArq FP01); adicionalmente, se enviará el vínculo para la descarga de la versión digital.

También se enviará una constancia informativa en la que se relaciona la publicación del artículo y, de manera opcional, se pueden detallar las fechas del proceso editorial y el arbitraje realizado. 
La selección de revisores se realiza de acuerdo con los siguientes criterios:

- Afinidad temática.

- Formación académica.

- Experiencia investigativa y profesional.

- Producción editorial en revistas similares o en libros resultado de investigación.

El proceso de arbitraje se basa en los principios de equidad e imparcialidad, y en los criterios de calidad y pertinencia.

El desarrollo de la revisión se realiza según el formato (RevArq FP10 Evaluación de artículos) y las observaciones que el revisor considere necesarias en el cuerpo del artículo. En cualquiera de los conceptos que emita el revisor (Aceptar, Publicable con modificaciones, Reevaluable o No publicable), y como parte de la labor formativa y de comunidad académica, el revisor hará sugerencias para mejorar el documento. El revisor podrá solicitar una nueva relectura del artículo después de los ajustes realizados por el autor.

El revisor también deberá diligenciar el formato RevArq FP01 Hoja de Vida, con el fin de certificar y soportar el proceso de revisión ante los SIR que así lo soliciten.

En el proceso de arbitraje se emplea el método doble ciego, los nombres del revisor no serán conocidos por el autor y viceversa. Con el fin de garantizar el anonimato del autor, al artículo postulado se le han podido suprimir nombres, instituciones o imágenes que puedan ser asociadas de manera directa al autor.

Aunque se procura el anonimato, una vez recibida la invitación como par revisor del artículo, el revisor debe cerciorarse de que no exista conflicto de intereses (CDI) o alguna limitante que afecte la revisión o que pueda ser vista como tal (lazos familiares, amistad o enemistad, vínculos contractuales o laborales, posiciones éticas, etc.), de presentarse esta situación se notificara al editor. (Ver modelo RevArq FP06 CDI).

Dada la confidencialidad del proceso de revisión, y considerando los derechos de autor y de propiedad intelectual que pueda haber sobre el material que se entrega, el revisor se compromete a mantener en absoluta reserva su labor, a limitar el uso de la obra entregada solo para el propósito designado y a devolver la documentación remitida una vez concluya la actividad.

El tiempo establecido para las revisiones de pares es de máximo un mes a partir de la confirmación de la recepción de la documentación. Ese plazo podrá ser modificado de mutuo acuerdo entre el editor y el revisor, siempre y cuando no afecte la periodicidad de la revista, la impresión o el tiempo para emitir una respuesta al autor.

Los revisores se acogerán a "COPE Ethical Guidelines for Peer Reviewers" de COPE.

\section{Beneficios}

Como retribución a los revisores se les hará envío postal de un ejemplar de la edición impresa sin ningún costo y entregada en la dirección consignada en el formato de hoja de vida. También, si es de interés para el revisor, podrá hacer la solicitud de alguna de las publicaciones editadas y presentes en el catálogo de publicaciones de la UNIVERSIDAD CATÓlica de Colombia, previa aprobación de la Editorial y sujeto a la disponibilidad.

Si lo desea tendrá derecho a una constancia de la colaboración en la revisión de artículos, la cual solo contendrá el periodo en el cual se realizó la actividad. También tendrá la posibilidad de aceptar o no la publicación de su nombre, nacionalidad y nivel máximo de formación en la página web de la Revista de Arquitectura en su calidad de colaborador.

\section{A) Proceso de revisión por pares}

Luego de la postulación del artículo, el editor de la Revista de Arquitectura selecciona y clasifica los artículos que cumplen con los requisitos establecidos en las directrices para los autores. El editor podrá rechazar en primera instancia artículos, sin recurrir a un proceso de revisión, si los considera de baja calidad o por presentar evidencias de faltas éticas o documentación incompleta.

Los artículos se someterán a un primer dictamen del editor, de los editores de sección y del Comité Editorial, teniendo en cuenta:

- Afinidad temática, relevancia del tema y correspondencia con las secciones definidas.

- Respaldo investigativo.

- Coherencia en el desarrollo del artículo, así como una correcta redacción y ortografía.
- Relación entre las figuras y tablas con el texto del artículo.

En esta revisión se verificará el nivel de originalidad mediante el uso de software especializado (Ithenticate o similar) y recursos digitales existentes para tal fin, también se observará la coherencia y claridad en los apartados del documento (modelo IMRYD), la calidad de las fuentes y la adecuada citación, esto quedará consignado en el formato (RevArq FP09 Revisión de artículos); esta información será cargada a la plataforma de gestión editorial y estará a disposición del autor.

En caso de que el artículo requiera ajustes preliminares, será devuelto al autor antes de ser remitido a revisores. En este caso, el autor tendrá veinte días para remitir nuevamente el texto con los ajustes solicitados.

Después de la preselección se asignan mínimo dos revisores especializados, quienes emitirán su concepto utilizando el formato (RevArq FP10 Evaluación de artículos) y las anotaciones que consideren oportunas en el texto; en esta etapa se garantizará la confidencialidad y el anonimato de autores y revisores (modalidad doble ciego).

Del proceso de revisión se emite uno de los siguientes conceptos que será reportado al autor:

- Aceptar el envío: con o sin observaciones.

- Publicable con modificaciones: se podrá sugerir la forma más adecuada para una nueva presentación, el autor puede o no aceptar las observaciones según sus argumentos. Si las acepta, cuenta con quince días para realizar los ajustes pertinentes.

- Reevaluable: cumple con algunos criterios y debe ser corregido. Es necesario hacer modificaciones puntuales y estructurales al artículo. En este caso, el revisor puede aceptar o rechazar hacer una nueva lectura del artículo luego de ajustado.

- No publicable: el autor puede volver a postular el artículo e iniciar nuevamente el proceso de arbitraje, siempre y cuando se evidencien los ajustes correspondientes.

En el caso de presentarse diferencias sustanciales y contradictorias en los conceptos sobre la recomendación del revisor, el editor remitirá el artículo a un revisor más o a un miembro del Comité Editorial quien podrá actuar como tercer árbitro, con el fin de tomar una decisión editorial sobre la publicación del artículo.

Los autores deberán considerar las observaciones de los revisores o de los editores, y cada corrección incorporada u omitida debe quedar justificada en el texto o en una comunicación adjunta. En el caso que los autores omitan las indicaciones realizadas sin una argumentación adecuada, el artículo será devuelto y no se dará por recibido hasta que no exista claridad al respecto.

El editor respetará la independencia intelectual de los autores y a estos se les brindará el derecho de réplica en caso de que los artículos hayan sido evaluados negativamente y rechazados.

Los autores, con su usuario y contraseña, podrán ingresar a la plataforma de Gestión Editorial, donde encontrarán los conceptos emitidos y la decisi sobre el artículo.

El editor y el Comité Editorial se reservan el derecho de aceptar o no la publicación del material recibido. También se reservan el derecho de sugerir modificaciones de forma, ajustar las palabras clave o el resumen y de realizar la corrección de estilo. El autor conocerá la versión final del texto antes de la publicación oficial del mismo.

Cuando un artículo es aceptado para su publicación, el autor debe firmar la autorización de reproducción (RevArq FP03 Autorización reproducción). Para más información ver: Política de derechos de autor

\section{Notas aclaratorias:}

La Revista de Arquitectura publica un número limitado de artículos por volumen y busca el equilibrio entre las secciones, motivo por el cual, aunque un artículo sea aceptado o continúe en proceso de revisión, podrá quedar aplazado para ser publicado en un próximo número; en este caso, el autor estará en la posibilidad de retirar la postulación del artículo o de incluirlo en el banco de artículos del próximo número.

El editor y los editores de sección de la Revista de Arquitectura son los encargados de establecer contacto entre los autores y revisores, ya que estos procesos se realizan de manera anónima.
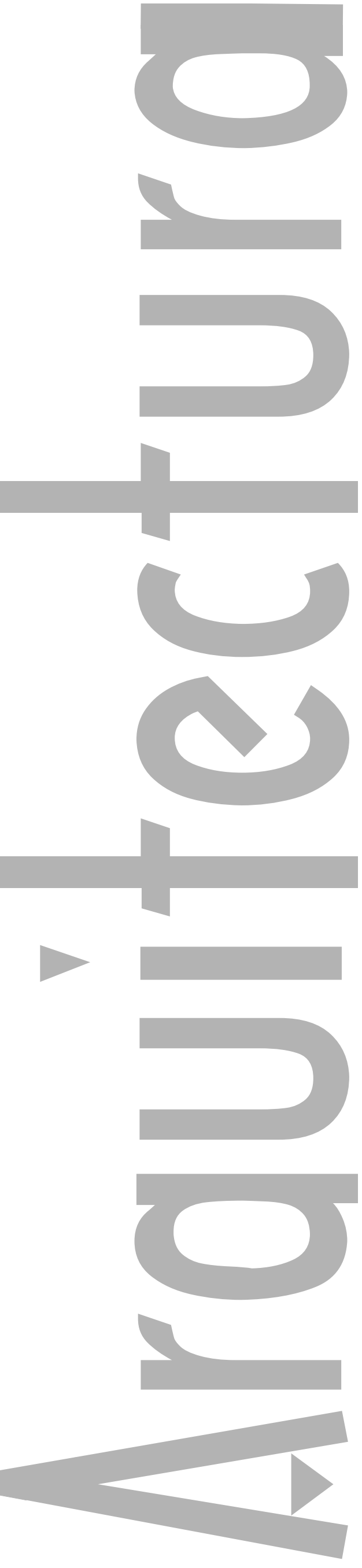
Estructura de indicadores de habitabilidad del espacio público en ciudades latinoamericanas

ن Structure of indicators of public space habitability in Latin American cities

Pablo Páramo,Andrea Burbano, Diana Fernández-Londoño

Além do público/privado

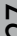
no Rio de Janeiro

Más allá de lo público y lo privado. Intervenciones temporales y creación de espacios colectivos en Río de Janeiro

Beyond the public and the private. temporary interventions and the creation of collective spaces in Rio de Janeiro

Conservar o renovar: dinámicas de histórico de tres

ciudades intermedias patrimoniales

U Una mirada a través de las licencias urbanísticas

To preserve or to renovate: Construction dynamics in the historic center of three intermediate-sized heritage cities. A look through urban planning permits

\section{Lida Buitrago-Campos}

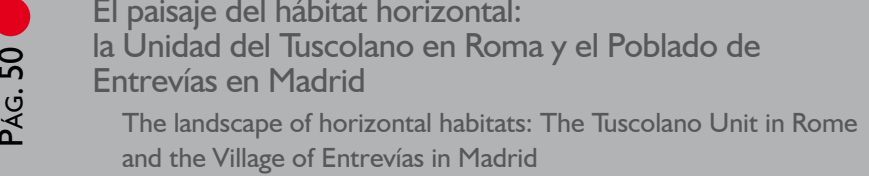

Evolución paralela del relato fílmico y la arquitectura de ㅇ. los cines entre 1900 y 1930

Atención especial al caso españo

¿ Parallel evolution of cinematographic stories and the architecture of cinemas between 1900 and 1930, with a special attention to the Spanish case

\section{Ana C. Lavilla-Iribarren}

El plan, acto mesiánico del proyectista

- La situación histórica del diseño en la utopía

₹. modernizante

The plan, a messianic act of the project architect. The historica situation of design in the modernizing utopia

Resiliencia a inundaciones: nuevo paradigma para el diseño urbano

ن Flood resilience: A new paradigm for urban design

¿ Resilience to flooding: new paradigm to urban design

Luis Fernando Molina-Prieto

Acceso solar en la arquitectura y la ciudad

ผ

Aproximación histórica

Solar access in architecture and the city. Historical approach

这

Campus universitario sustentable

ô

Sustainable university campus

نำ

Lina Johanna Zapata-González,Andrés Quiceno-Hoyos,
Luisa Fernanda Tabares-Hidalgo

La crítica arquitectónica como objeto de investigación

[La critique architecturale, objet de recherche]

Architectural criticism as an object of research

ن் Hélène Jannière 